\title{
Photosynthesis is differently regulated during and after copper-induced nutritional stress in citrus trees
}

Franz W.R. Hippler ${ }^{\mathrm{ab},{ }^{*}}$, Veronica L. Dovis ${ }^{\mathrm{a}}$, Rodrigo M. Boaretto ${ }^{\mathrm{a}}$, Jose A. Quaggio ${ }^{\mathrm{c}}$, Ricardo A. Azevedo $^{\mathrm{b}}$, Lorraine E. Williams ${ }^{\mathrm{d}}$, Dirceu Mattos-Jr ${ }^{\mathrm{a}, *}$

${ }^{\mathrm{a} C e n t r o ~ d e ~ C i t r i c u l t u r a ~ S y l v i o ~ M o r e i r a, ~ I n s t i t u t o ~ A g r o n o ̂ m i c o, ~ R o d . ~ A n h a n g u e r a, ~ k m ~ 158, ~ C P ~ 04, ~ C E P ~}$ 13490-970, Cordeirópolis, SP, Brazil

${ }^{\mathrm{b}}$ Departamento de Genética, Escola Superior de Agricultura Luiz de Queiroz, CP 9, Universidade de São Paulo, 13418-900, Piracicaba, SP, Brazil

${ }^{\mathrm{c}}$ Centro de Solos e Recursos Ambientais, Instituto Agronômico, Av. Barão de Itapura, 1481, CP 28, CEP 13020-902, Campinas, SP, Brazil

${ }^{\mathrm{d} B i o l o g i c a l ~ S c i e n c e s, ~ U n i v e r s i t y ~ o f ~ S o u t h a m p t o n, ~ L i f e ~ S c i e n c e s ~ B u i l d i n g ~ 85, ~ H i g h f i e l d ~ C a m p u s, ~}$ Southampton SO17 1BJ, United Kingdom

\section{Correspondence}

*Corresponding authors,

e-mails: franz@,ccsm.br; $\underline{\text { ddm@.ccsm.br }}$

Antioxidant enzymatic responses in Citrus leaves under $\mathrm{Cu}$-induced stress depends on rootstock genotypes. However, there is a lack of information about how woody plants recover growth capacity after exposure to elevated $\mathrm{Cu}$ and whether growth is affected by the redistribution of the metal to new vegetative parts and consequently whether photosynthesis is affected. Therefore, the biomass of plants and $\mathrm{Cu}$ concentrations in new leaf flushes were determined in young citrus trees grafted onto contrasting rootstocks [Swingle citrumelo (SW) and Rangpur lime (RL)]. Photosynthetic rate, chlorophyll fluorescence and antioxidant enzymatic systems were evaluated in plants previously grown in nutrient solution with $\mathrm{Cu}$ varying from low to high levels and with no added $\mathrm{Cu}$. Both rootstocks exhibited reduced plant growth under $\mathrm{Cu}$ toxicity. However, trees grafted onto $\mathrm{RL}$ exhibited better growth recovery after $\mathrm{Cu}$ excess, which was dependent on the modulation of antioxidant enzyme activities in roots and leaves that maintained the integrity of the photosynthetic apparatus. In contrast, plants grafted onto SW exhibited a lower photosynthetic rate at the lowest This article has been accepted for publication and undergone full peer review but has not been through the copyediting, typesetting, pagination and proofreading process which may lead to differences between this version and the Version of Record. Please cite this article as doi: $10.1111 / \mathrm{ppl} .12746$ 
available $\mathrm{Cu}$ concentration. Although the highest accumulation of $\mathrm{Cu}$ occurred in citrus roots, the redistribution of the nutrient to new vegetative parts was proportional to the $\mathrm{Cu}$ concentration in the roots.

Abbreviations - $\mathrm{F} / \mathrm{F}_{\mathrm{M}} 2$ effective quantum yield of PSII; AEF, alternative electron flow; APX, ascorbate peroxidase; $\mathrm{CAT}$, catalase; $C_{i}$, internal $\mathrm{CO}_{2}$ concentration; ETR, apparent electron transport rate; $\mathrm{F}_{\mathrm{V}} / \mathrm{F}_{\mathrm{M}}$, maximum quantum yield of PSII; $g_{S}$, stomatal conductance; $\mathrm{H}_{2} \mathrm{O}_{2}$, hydrogen peroxide; MDA, lipid peroxidation; $\mathrm{O}_{2}{ }^{-}$, superoxide anion; $P_{N}$, net photosynthetic rate; PPFD, photosynthetic photon flux density; PS, photosystem; qNP, non-photochemical quenching; qP, photochemical quenching; ROS, reactive oxygen species; SOD, superoxide dismutase; VPD, vapor pressure deficit.

\section{Introduction}

Copper $(\mathrm{Cu})$ nutritional disorders cause impairment of plant growth and citrus production losses. Copper deficiency is observed in nursery and non-bearing citrus trees supplied with high nitrogen $(\mathrm{N})$ rates or grown in soils with high $\mathrm{pH}$ and organic matter/clay content (Mattos Jr et al. 2010, Hippler et al. 2018a). On the other hand, $\mathrm{Cu}$ excess has been associated with metal accumulation in soils, which results from continuous applications of $\mathrm{Cu}$-based fungicides for plant protection (Komárek et al. 2009, Fan et al. 2011). In this case, amounts of $\mathrm{Cu}$ applied in citrus orchards are likely to increase due to the enhanced incidence of citrus canker in growing areas as observed in Florida (USA) and São Paulo state (Brazil) after the suspension of eradication programs against disease affecting trees (Behlau et al. 2016).

Under $\mathrm{Cu}$-induced stress conditions, caused either by deficiency or toxicity, reactive oxygen species (ROS) increase in plants (Hippler et al. 2016, 2018a). The accumulation of ROS in cells affects membranes and the cell wall by degrading proteins, lipids and DNA, consequently affecting the cellular metabolism (Cuypers et al. 2016). Photosynthesis is one of the most highly disturbed processes influenced by ROS; photosynthesis suboptimal functioning impacts growth and hence the fruit yield of trees (Syvertsen and Garcia-Sanchez 2014, Zandalinas et al. 2017). Plants generally contain enzymatic and non-enzymatic antioxidant systems to provide tolerance to biotic and abiotic stresses and consequently alleviate damages caused by ROS (Juraniec et al. 2013, Piotto et al. 2014). Superoxide dismutase (SOD, EC 1.15.1.1) is the first enzyme that reduces the superoxide anion $\left(\mathrm{O}_{2}{ }^{-*}\right)$ 
to hydrogen peroxide $\left(\mathrm{H}_{2} \mathrm{O}_{2}\right)$. Then, the excess of $\mathrm{H}_{2} \mathrm{O}_{2}$ in cells is eliminated by catalase (CAT, EC 1.11.1.6), ascorbate peroxidase (APX, EC 1.11.1.11) or guaiacol peroxidase (Anjum et al. 2016).

In woody plants, such as citrus, different rootstock genotypes differentially regulate the absorption and distribution of nutrients into shoot parts (Martínez-Ballesta et al. 2010), they also influence the activity of antioxidant enzymes in the leaves by regulating root signalling processes (Hippler et al. 2016). The antioxidant system is recognized to be directly involved in heavy metal tolerance of plants (Gratão et al. 2015, Borges et al. 2018). In this context, the role of rootstocks and scions on the rootto-shoot communication and increased plant tolerance to cadmium $(\mathrm{Cd})$ toxicity were recently characterized (Gratão et al. 2015). For example, the activities of antioxidant enzymes in roots of grafted tomato plants improved tomato tolerance to metal excess, indicating the importance of root-toshoot stress signalling (Gratão et al. 2015). Under Cu excess, sweet orange trees grafted onto Rangpur lime [RL; Citrus limonia (L.) Osbeck] had higher enzyme activities in leaves than those grafted onto Swingle citrumelo [SW; C. paradisi Macf. x Poncirus trifoliata (L.) Raf.]. However, information about responses of the antioxidant enzyme system in roots of contrasting citrus rootstocks under $\mathrm{Cu}-$ induced stress remains unclear. The efficiency of the enzyme antioxidant system is a key component to maintain the integrity of the photosynthetic apparatus and leaf gas exchange for high fruit yield of citrus trees (Syvertsen and Garcia-Sanchez 2014). Understanding the efficacy of the antioxidant enzymes of RL and SW rootstocks in alleviating oxidative stress might support future strategies of citrus trees management in fields subjected to $\mathrm{Cu}$ nutritional disorders, since those rootstocks present $80 \%$ of the Brazilian citrus orchards.

Since rootstocks regulate $\mathrm{Cu}$ compartmentation in roots to maintain plant homeostasis (Zambrosi et al. 2013, Hippler et al. 2018b), they are also expected to affect $\mathrm{Cu}$ redistribution to new vegetative organs. The phloem mobility of metal micronutrients, such as manganese (Mn) and zinc ( $\mathrm{Zn})$ in citrus trees is very low (Hippler et al. 2015). However, there is still a need of information to elucidate the significance of $\mathrm{Cu}$ redistribution in relation to the development of new growing parts of woody plants. A comprehensive understanding on how rootstocks modulate physiological and biochemical aspects, as well as plant development, under deficiency or toxicity of $\mathrm{Cu}$ will contribute to the selection of suitable rootstocks genetic material supporting the sustainability of plant production. Therefore, this work aimed (i) to evaluate the performance and integrity of the photosynthetic apparatus, as well as the activity of antioxidant enzymes in response to $\mathrm{Cu}$ deficiency or toxicity in citrus trees grafted onto two rootstocks with contrasting horticultural characteristics and (ii) to assess the $\mathrm{Cu}$ redistribution in citrus trees and their growth capacity after suspension of the metal-nutrient supply. 


\section{Material and Methods}

\section{Plant material and growth conditions}

One-year-old sweet orange trees [Citrus sinensis (L.) Osbeck cv. Valencia] grafted onto Swingle citrumelo [SW; C. paradisi Macf. x Poncirus trifoliata (L.) Raf.] or Rangpur lime [RL; C. limonia (L.) Osbeck] were grown in a greenhouse. Plants were transferred from organic substrate to pots (one plant per pot) containing 111 of nutrient solution as described by Hippler et al. (2016). Plants were adapted to the hydroponic condition for two weeks at $25 \%$ of the concentration of the full nutrient solution and subsequently for two weeks at $50 \%$ of the full nutrient solution. Then, plants were maintained at the following concentration, in mM: $12 \mathrm{~N}\left(80 \% \mathrm{~N}^{-N^{2}}\right), 0.4 \mathrm{P}, 3.4 \mathrm{~K}, 4.0 \mathrm{Ca}, 25 \mathrm{Mg}$ and $20 \mathrm{~S}$, plus, in $\mu \mathrm{M}$ : 41.6 B, 48.0 Fe, 8.2 Mn, 3.5 $\mathrm{Zn}$ and 1.3 Mo (modified from Zambrosi et al. 2013). The experiment was set up in a completely randomised, $2 \times 3$ factorial design, with two rootstock genotypes (SW and RL) and three $\mathrm{Cu}$ concentrations in the nutrient solution (low: 0.015 , medium: 0.60 and high: $24.0 \mu \mathrm{M} \mathrm{CuSO}_{4} \cdot 5 \mathrm{H}_{2} \mathrm{O}$ ), with five replications. Treatments of $\mathrm{Cu}$ concentrations in the nutrient solution started after 45 days of plant adaptation to the full nutrient solution, when the first vegetative flush started sprouting (herein identified as old parts, Appendix S1). The nutrient solution was aerated continuously, and the volumes of the containers were kept constant by adding deionized water when necessary and were renewed at intervals of approximately 15 days. The $\mathrm{pH}$ of the nutrient solution was adjusted to 5.0-5.5 with additions of $1 \mathrm{M} \mathrm{KOH}$ or $1 \mathrm{M} \mathrm{H}_{2} \mathrm{SO}_{4}$.

When plants exhibited the second vegetative flush of physiologically mature leaves (identified as new parts), 110 days after starting treatments with $\mathrm{Cu}$, photosynthesis was evaluated (new leaves) and biochemical analyses (roots and new leaves, Period 1) were conducted to assess the effects of $\mathrm{Cu}$ treatments. The new parts (twigs and leaves) formed after starting the $\mathrm{Cu}$ treatments were destructively collected, and leaf area was measured (LI-3100C, LI-COR, Lincoln, NE). Plant material was washed and dried at $58-60^{\circ} \mathrm{C}$ to determine the mass production, and $\mathrm{Cu}$ and $\mathrm{Fe}$ tissue concentrations were determined by plasma emission spectrometry (ICP-OES, Perkin Emler 5100 PC, Norwalk, CT) after nitro-perchloric digestion according to Bataglia et al. (1983).

In Period 2, we evaluated the growth capacity and the redistribution of $\mathrm{Cu}$ in plants after interrupting the metal-nutrient supply by changing the plants to a solution without $\mathrm{Cu}(<0.001 \mu \mathrm{M} \mathrm{Cu}$, Appendix S1). For this reason, just after the evaluations in Period 1, containers and root surfaces were passed through a washing process before starting with the $\mathrm{Cu}$-deprived solution to minimize a residual effect of $\mathrm{Cu}$ on the root surface. Then, roots and containers were rinsed with distilled water $\left({ }_{d} \mathrm{H}_{2} \mathrm{O}\right)$, 
quickly immersed in a solution of $200 \mathrm{mM}$ ethylenediaminetetraacetic acid (EDTA) and again rinsed with ${ }_{d} \mathrm{H}_{2} \mathrm{O}$. At 140 days after the first evaluation period ( 250 days after the start of treatments in Period 1), the second new vegetative flush was physiologically mature (Period 2, Appendix S1). At this point, evaluation of photosynthesis (new leaves) and sampling of roots and new leaves for biochemical analysis were repeated (Period 2). In Period 2, trees were destructively collected and separated into coarse $(>3 \mathrm{~mm} \varnothing)$ and fibrous roots $(\mathrm{d} 3 \mathrm{~mm} \varnothing)$, twigs, and leaves from the older part (existing before the start of the treatments) and the newer part (grown after starting the treatment of Period 2) for the determination of dry mass production and $\mathrm{Cu}$ and $\mathrm{Fe}$ concentrations in plant tissues (Bataglia et al. 1983). The accumulation and partition of $\mathrm{Cu}$ were estimated based on dry mass and the nutrient concentration in plant parts.

\section{Gas exchange and chlorophyll a fluorescence measurements}

The net photosynthetic rate $\left(\mathrm{P}_{\mathrm{N}}\right)$, stomatal conductance to water vapor $\left(\mathrm{g}_{\mathrm{S}}\right)$ and internal $\mathrm{CO}_{2}$ concentration $\left(\mathrm{C}_{\mathrm{i}}\right)$ were determined in sun-exposed and recently expanded leaves in the middle third of twigs from the new part. The evaluations were performed on a clear day between 9:00 and 11:00 with an infrared gas analyser open system LI-6400 (LI-COR, Lincoln, NE) equipped with an integrated fluorescence chamber head (LI-6400-40, LI-COR), at ambient temperature [vapor pressure deficit (VPD) of $1.32 \mathrm{kPa}$ in Period 1 and $1.94 \mathrm{kPa}$ in Period 2], at $40 \mathrm{~Pa} \mathrm{CO}_{2}$ partial pressure and under artificial photosynthetic photon flux density (PPFD) $800 \mu \mathrm{mol} \mathrm{m}^{-2} \mathrm{~s}^{-1}$ at the leaf level.

Steady-state $\left(\mathrm{F}_{\mathrm{O}}{ }^{\prime}\right)$ and maximum $\left(\mathrm{F}_{\mathrm{M}}{ }^{\prime}\right)$ fluorescence yield were assessed in light adapted leaf tissues, whereas minimum $\left(\mathrm{F}_{\mathrm{O}}\right)$ and maximum $\left(\mathrm{F}_{\mathrm{M}}\right)$ fluorescence yields were carried out in darkadapted (over-night) leaf tissues. $\mathrm{F}_{\mathrm{M}}$ and $\mathrm{F}_{\mathrm{M}}$ were measured after a light saturation pulse $[\gg<710 \mathrm{~nm}$, PPFD 10,000 $\mu \mathrm{mol}$ (photon) $\mathrm{m}^{-2} \mathrm{~s}^{-1}, 0.8 \mathrm{~s}$. The variable fluorescence yield in both dark-adapted $\left(\mathrm{F}_{\mathrm{V}}=\mathrm{F}_{\mathrm{M}}-\mathrm{F}_{\mathrm{O}}\right)$ and light-adapted $\left(\mathrm{F}_{\mathrm{V}}{ }^{\prime}=\mathrm{F}_{\mathrm{M}}{ }^{\prime}-\mathrm{F}_{\mathrm{O}}{ }^{\prime}\right)$ leaves was calculated. The maximum quantum yield of PSII $\left[F_{V} / F_{M}=\left(F_{M}-F_{O}\right) / F_{M}\right]$, the effective quantum yield of PSII $\left[F / F_{M} z=\left(F_{M} 2 F_{S}\right) / F_{M}\right.$ ], the alternative electron flow $\left[\mathrm{AEF}=\left(\mathrm{F} / \mathrm{F}_{\mathrm{M}}{ }^{\prime}\right) /\left(\mathrm{P}_{\mathrm{N}} /(\mathrm{PPFD} \times 0.84)\right)\right]$, the photochemical quenching coefficient $\left[\mathrm{qP}=\left(\mathrm{F}_{\mathrm{M}} 2 \mathrm{~F}_{\mathrm{S}}\right) /\left(\mathrm{F}_{\mathrm{M}} 2 \mathrm{~F}_{\mathrm{O}} 2\right]\right.$, and the non-photochemical quenching coefficient [qNP $\left.=\left(\mathrm{F}_{\mathrm{M}}-\mathrm{F}_{\mathrm{M}} 2\right) /\left(\mathrm{F}_{\mathrm{M}}-\mathrm{F}_{\mathrm{O}} 2\right)\right]$ were calculated (Schreiber et al. 1994). The apparent electron transport rate $\left[\mathrm{ETR}=\mathrm{F} / \mathrm{F}_{\mathrm{M}} 2 \times \mathrm{PPFD} \times 0.84 \times 0.5\right]$ was calculated according to Genty et al. (1989). The ratio ETR $/ \mathrm{P}_{\mathrm{N}}$ was calculated to estimate the use of electrons in other processes not related to the photosynthetic $\mathrm{CO}_{2}$ assimilation rate. 


\section{Hydrogen peroxide, lipid peroxidation and antioxidant enzyme activities}

The measurements of the hydrogen peroxide $\left(\mathrm{H}_{2} \mathrm{O}_{2}\right)$ and lipid peroxidation (MDA) contents were performed from the same extraction, in which $500 \mathrm{mg}$ of fresh mass of leaves (new parts) or fibrous roots $(\mathrm{d} 3 \mathrm{~mm} \varnothing)$ were homogenized in $5 \mathrm{ml}$ of $0.1 \%(\mathrm{w} / \mathrm{v})$ trichloroacetic acid (TCA) and centrifuged at $5590 \mathrm{~g}$ for $15 \mathrm{~min}$ at $4^{\circ} \mathrm{C}$ (Alexieva et al. 2001). For $\mathrm{H}_{2} \mathrm{O}_{2}$ content, the supernatant was mixed with $100 \mathrm{mM}$ potassium phosphate buffer (pH 7.0), and 1.0 M potassium iodide (1:1:4) and incubated at $4^{\circ} \mathrm{C}$ for $1 \mathrm{~h}$ in darkness and then for $20 \mathrm{~min}$ at $25^{\circ} \mathrm{C}$ before measuring the absorbance at $390 \mathrm{~nm}$. The amount of hydrogen peroxide was calculated using a standard curve with known concentrations of $\mathrm{H}_{2} \mathrm{O}_{2}$. The lipid peroxidation was determined according to Heath and Packer (1968). To the supernatant sample, $1 \mathrm{ml}$ of a solution containing $20 \%(\mathrm{w} / \mathrm{v})$ TCA and $0.5 \%(\mathrm{w} / \mathrm{v})$ thiobarbituric acid (TBA) was added, and then incubated at $95^{\circ} \mathrm{C}$ for $30 \mathrm{~min}$ followed by a quick cooling at $4^{\circ} \mathrm{C}$ to stop the reaction. The samples were re-centrifuged for $5 \mathrm{~min}$ at $12100 \mathrm{~g}$, and the supernatant was measured at 535 and $600 \mathrm{~nm}$. The absorbance of the formed TBA reactive substances was determined at $535 \mathrm{~nm}$. Measurements were corrected for unspecific turbidity by subtracting the absorbance at $600 \mathrm{~nm}$. The amount of MDA was calculated using an extinction coefficient of $155 \mathrm{mM}^{-1} \mathrm{~cm}^{-1}$.

For protein quantification and enzyme activities, $1 \mathrm{~g}$ of fine leaves or fibrous root powder was homogenized in $5.0 \mathrm{ml}$ of $100 \mathrm{mM}$ potassium phosphate buffer (pH 7.5), with $3 \mathrm{mM}$ dithiothreitol, 1 $\mathrm{mM}$ EDTA and 4\% (w/v) polyvinylpolypyrrolidone (Gratão et al. 2015). The suspension was centrifuged at $12100 \mathrm{~g}$ at $4{ }^{\circ} \mathrm{C}$ for $35 \mathrm{~min}$, and the supernatant was stored at $-80^{\circ} \mathrm{C}$ for further analysis. The total protein content was determined using bovine serum albumin as a standard (Bradford 1976).

Superoxide dismutase (SOD) activity staining was carried out according to Beauchamp and Fridovich (1971), with modifications (Hippler et al. 2015). Electrophoresis was carried out under nondenaturing conditions in $12 \%$ polyacrylamide gel (PAGE) with $50 \mu \mathrm{g}$ proteins per lane for leaves and $75 \mu \mathrm{g}$ for root samples. One unit of bovine liver SOD (Sigma, St. Louis, MO) was used as a positive control of activity. After non-denaturing PAGE separation, the gel was incubated in the dark in 50 $\mathrm{mM}$ potassium phosphate buffer $(\mathrm{pH} 7.8)$ containing $1 \mathrm{mM}$ EDTA, $0.05 \mathrm{mM}$ riboflavin, $0.1 \mathrm{mM}$ nitroblue tetrazolium, and $0.3 \% \quad \mathrm{~N}, \mathrm{~N}, \mathrm{~N}^{\prime}, \mathrm{N}^{\prime}$-tetramethylethylenediamine. SOD isoenzyme characterization was performed as described by Azevedo et al. (1998). Briefly, SOD isoenzymes were distinguished by their sensitivity to inhibition by $2 \mathrm{mM}$ potassium cyanide and $5 \mathrm{mM} \mathrm{H}_{2} \mathrm{O}_{2}$. Catalase (CAT) activity was determined according to Kraus et al. (1995) with modifications (Azevedo et al. 1998) and ascorbate peroxidase (APX) was determined by the method of Nakano and Asada (1981), 
both as described in Hippler et al. (2016). CAT activity was calculated by using an extinction coefficient of $39.4 \mathrm{M}^{-1} \mathrm{~cm}^{-1}$ and APX by $2.8 \mathrm{mM}^{-1} \mathrm{~cm}^{-1}$.

\section{Statistical analysis}

To analyse the studied factors and their interactions, analysis of variance (ANOVA) was used at $P<0.05$. When the interaction between $\mathrm{Cu}$ levels and citrus rootstocks ( $\mathrm{Cu} * \mathrm{RT})$ was significant, means were compared using the Tukey test $( \pm=0.05)$.

\section{Results}

\section{Plant growth under different $\mathrm{Cu}$ treatments}

After 110 days of exposure to different levels of $\mathrm{Cu}($ Period 1), the highest concentration of $\mathrm{Cu}$ in the nutrient solution $(24.0 \mu \mathrm{M} \mathrm{Cu})$ reduced the biomass production of twigs and leaves (new parts) and leaf area, compared to the medium level of $\mathrm{Cu}(0.60 \mu \mathrm{M} \mathrm{Cu}$, Fig. 1). Trees grafted onto Rangpur lime (RL) exhibited higher dry mass (DM) of twigs and young leaves, especially in the highest concentration of $\mathrm{Cu}$, they also exhibited greater leaf area at concentrations of 0.60 and $24.0 \mu \mathrm{M} \mathrm{Cu}$, both compared to those grafted onto SW (Fig. 1).

In Period 2, the orange trees grafted onto RL exhibited lower biomass production and leaf area upon $\mathrm{Cu}$-deprivation compared when previously grown in $0.015 \mu \mathrm{M} \mathrm{Cu}$ (Fig. 1). Plants that received 24.0 $\mu \mathrm{M} \mathrm{Cu}$ in Period 1 had greater biomass production in the Period 2, with a total DM similar to those grown in $0.60 \mu \mathrm{M} \mathrm{Cu}$ (Fig. 1). The biomass production of trees grafted on SW did not differ among the $\mathrm{Cu}$ concentrations, but the smallest leaf area was observed under the highest concentration of $\mathrm{Cu}$ (Fig. 1).

\section{$\mathrm{Cu}$ uptake and distribution in grafted citrus plants}

The uptake and distribution of $\mathrm{Cu}$ in citrus plants grafted onto contrasting rootstocks were assessed at the end of Period 1, when levels of the nutrient varied in the nutrient solution, as well as in Period 2, when the same plants were grown without $\mathrm{Cu}$. The $\mathrm{Cu}$ concentration in the new vegetative flush (leaves and twigs) of trees on both rootstocks increased proportionally to the $\mathrm{Cu}$ concentration in the nutrient solution in both periods (Fig. 2). However, in Period 1, trees grafted onto RL accumulated more $\mathrm{Cu}$ in new parts of the plants, such as fibrous roots, new leaves and new twigs, when grown in $24.0 \mu \mathrm{M} \mathrm{Cu}$, compared to those grafted onto SW (Fig. 3). 
At the end of the Period 2 (without $\mathrm{Cu}$ supply), plants previously grown in $24.0 \mu \mathrm{M} \mathrm{Cu}$ exhibited the highest metal accumulation and partition into the roots, about 3.4-fold more than in old twigs, whereas those grown in $0.015 \mu \mathrm{M} \mathrm{Cu}$ showed similar partitioning of the metal between the old twigs and roots, which represented approximately $80 \%$ of the total $\mathrm{Cu}$ in the plant (Fig. 3). Although plants in both rootstocks exhibited higher $\mathrm{Cu}$ partition into the roots, metal accumulation in those grafted onto RL was similar for both fibrous and coarse roots, while in the same plants grafted onto SW, the metal accumulation occurred mainly in the coarse roots (Fig. 3). No differences in $\mathrm{Cu}$ partition were seen for other plant parts (Fig. 3).

The Fe concentration increased in roots and decreased in leaves with the highest concentration of $\mathrm{Cu}$ in the nutrient solution (Fig. 4), as observed previously (Hippler et al. 2016). Furthermore, in this study, we demonstrated that plants accumulated more Fe in the coarse roots of SW (5.1 $\mathrm{mg}$ of $\mathrm{Fe}$ ) compared to those of RL ( $2.2 \mathrm{mg}$ of $\mathrm{Fe}, P<0.01)$. On the other hand, we observed the opposite for fibrous roots: $5.1 \mathrm{mg}$ of $\mathrm{Fe}$ for RL and $3.3 \mathrm{mg}$ of Fe for SW (Fig. 4).

\section{Leaf gas exchange and chlorophyll fluorescence in citrus plants during and after $\mathrm{Cu}$-induced stress}

In the first period, the photosynthetic rate $\left(\mathrm{P}_{\mathrm{N}}\right)$, stomatal conductance $\left(g_{S}\right)$, apparent electron transport rate (ETR), and instantaneous carboxylation efficiency $\left(\mathrm{P}_{\mathrm{N}} / \mathrm{C}_{\mathrm{i}}\right)$ were higher in trees grown in $0.60 \mu \mathrm{M} \mathrm{Cu}$, especially those grafted onto RL (Fig. 5). The internal $\mathrm{CO}_{2}$ concentration $\left(\mathrm{C}_{\mathrm{i}}\right)$ varied with $\mathrm{Cu}$ concentrations only in trees grafted onto $\mathrm{RL}$, with the highest $C_{i}$ being in those grown in $24.0 \mu \mathrm{M}$ $\mathrm{Cu}\left(225 \mu \mathrm{mol} \mathrm{mol}^{-1}\right)$ and the lowest grown in $0.60 \mu \mathrm{M} \mathrm{Cu}\left(155 \mu \mathrm{mol} \mathrm{mol}^{-1}\right.$, Fig. 5). In Period 2, trees grafted onto SW and grown in nutrient solution containing 0.015 or $0.60 \mu \mathrm{M} \mathrm{Cu}$ were more sensitive to the limitation of the nutrient than those grafted onto $\mathrm{RL}$, as verified by the lower values of $\mathrm{P}_{\mathrm{N}}, \mathrm{g}_{\mathrm{S}}$ and $\mathrm{P}_{\mathrm{N}} / \mathrm{C}_{\mathrm{i}}$, and the highest values of ETR/ $\mathrm{P}_{\mathrm{N}}$ (Fig. 5). Plants grafted onto RL and grown in $24.0 \mu \mathrm{M} \mathrm{Cu}$ presented similar values of $\mathrm{P}_{\mathrm{N}}, \mathrm{g}_{\mathrm{S}}$, and $\mathrm{C}_{\mathrm{i}}$ in Period 1 and Period 2, while trees grafted onto $\mathrm{SW}$ presented increases after the Period 1 (Fig. 5).

In Period 1 , no differences in the potential quantum yield of PSII $\left(\mathrm{F}_{\mathrm{V}} / \mathrm{F}_{\mathrm{M}}\right)$, or for photochemical (qP) or non-photochemical quenching (qNP) (Fig. 6) were monitored for varying $\mathrm{Cu}$ concentrations. Nevertheless, the effective quantum yield of PSII ( $\left.\mathrm{F} / \mathrm{F}_{\mathrm{M}}{ }^{\prime}\right)$ was lower in plants grown either at the lowest or at the highest $\mathrm{Cu}$ concentration in the nutrient solution (Fig. 6). Furthermore, the alternative electron flows (AEF) were higher in trees grafted onto SW grown in both 0.015 or $24.0 \mu \mathrm{M} \mathrm{Cu}$ compared to those grown in $0.60 \mu \mathrm{M} \mathrm{Cu}$, whereas the $\mathrm{AEF}$ for trees grafted onto RL was only higher 
in $0.15 \mu \mathrm{M} \mathrm{Cu}$, compared to the other $\mathrm{Cu}$ concentrations (Fig. 6). In the second period, plants grown in $24.0 \mu \mathrm{M} \mathrm{Cu}$ exhibited higher values of $\mathrm{F} / \mathrm{F}_{\mathrm{M}}$ ', $\mathrm{qP}$ and $\mathrm{qNP}$, mainly when compared to those grown in $0.015 \mu \mathrm{M} \mathrm{Cu}$ (Fig. 6), in which trees grafted onto RL with the lowest $\mathrm{Cu}$ concentration exhibited lower qP than those grafted onto SW (Fig. 6). The highest value of AEF was observed in plants grafted onto SW grown in the lowest $\mathrm{Cu}$ concentration, whereas those grafted onto RL had an AEF value only higher when trees were grown in $24.0 \mu \mathrm{M} \mathrm{Cu}$ (Fig. 6).

\section{Oxidative stress levels induced by $\mathrm{Cu}$-stress and antioxidant enzyme responses of citrus rootstocks}

The $\mathrm{H}_{2} \mathrm{O}_{2}$ and MDA contents in the first period were higher in leaves and roots of plants grown in $24.0 \mu \mathrm{M} \mathrm{Cu}$; this was also observed at a lower intensity in plants grown in solution with low availability of $\mathrm{Cu}(0.015 \mu \mathrm{M} \mathrm{Cu})$ compared to those grown in solution with adequate $\mathrm{Cu}$ concentration (Fig. 7). In Period 2, plants grafted onto SW grown in the lower and higher $\mathrm{Cu}$ concentrations presented similar $\mathrm{H}_{2} \mathrm{O}_{2}$ and MDA contents than during Period 1, while the $\mathrm{H}_{2} \mathrm{O}_{2}$ concentration in leaves and roots and MDA in leaves of plants grafted onto RL was reduced when the $\mathrm{Cu}$ supply in the nutrient solution was suspended (Fig. 7). However, plants grown in $0.015 \mu \mathrm{M} \mathrm{Cu}$, for both rootstocks, presented an increase in $\mathrm{H}_{2} \mathrm{O}_{2}$ levels in roots and MDA in leaves (Fig. 7).

The activity of the SOD isoforms differed between the $\mathrm{Cu}$ concentrations and rootstocks, both in the leaves and the roots (Fig. 8). Moreover, the $\mathrm{Cu} / \mathrm{Zn}$-SOD activity in the leaves increased according to the $\mathrm{Cu}$ concentration in solution. For orange trees grafted onto SW, an increase in activity was observed for the isoform $\mathrm{Cu} / \mathrm{Zn}$-SOD III, while for trees grafted onto RL, both $\mathrm{Cu} / \mathrm{Zn}$-SOD II and III increased activity (Fig. 8A). Seven isoforms of SOD were identified in roots of both rootstock genotypes: three Fe-SOD, two Mn-SOD and two Cu/Zn-SOD (Fig. 8). Increases in the activity of $\mathrm{Cu} / \mathrm{Zn}$-SOD, especially the $\mathrm{Cu} / \mathrm{Zn}$-SOD II in both rootstocks, were correlated with increases of $\mathrm{Cu}$ concentration in the nutrient solution (Fig. 8). On the contrary of what observed for $\mathrm{Cu} / \mathrm{Zn}$-SOD, the $\mathrm{Fe}-\mathrm{SOD}$ activity in roots was reduced with increased $\mathrm{Cu}$ concentration in the nutrient solution (Fig. $8 \mathrm{~B}$ ). In Period 2, the SOD activity was reduced in leaves and roots compared to the first period (Figs. $8 \mathrm{C}$ and $8 \mathrm{D}$ ). Trees grown in $0.015 \mu \mathrm{M} \mathrm{Cu}$ in the nutrient solution exhibited higher activities of MnSOD I and II isoforms in leaves independently of the rootstocks used (Fig. 8). Furthermore, the activity of $\mathrm{Cu} / \mathrm{Zn}$-SOD III was observed only in SW-trees grown in $0.015 \mu \mathrm{M} \mathrm{Cu}$ and RL-trees grown in $24.0 \mu \mathrm{M} \mathrm{Cu}$ (Fig. 8C). In roots, the activity of $\mathrm{Cu} / \mathrm{Zn}$-SOD increased with $\mathrm{Cu}$ concentrations in the first period, and this was higher for trees grafted onto RL (Fig. 8). Trees grafted onto SW exhibited 
higher activities of Mn-SOD I and II than those grown in 0.015 and $24.0 \mu \mathrm{M} \mathrm{Cu}$, while in trees grafted onto RL, enzyme activity was only detected for the Mn-SOD II for all Cu treatments (Fig. 8).

The CAT activity in leaves and roots in Period 1 was higher when plants were grown in the lowest and highest $\mathrm{Cu}$ concentrations (Fig. 9). However, with the highest concentration of $\mathrm{Cu}$, the greatest CAT activity was verified in leaves of RL and in roots of SW (Fig. 9). In Period 2, CAT activity in leaves of trees grafted onto RL and grown in $24.0 \mu \mathrm{M} \mathrm{Cu}$ was higher than those grafted onto SW (Fig. 9). In the roots, the activity of CAT varied only in trees grafted onto RL that were grown with the highest concentration of $\mathrm{Cu}$ (Fig. 9).

For both rootstocks in the first period, the APX activity in leaves was higher in plants grown in $24.0 \mu \mathrm{M} \mathrm{Cu}$, followed by those grown in $0.015 \mu \mathrm{M} \mathrm{Cu}$, while APX activity increased in roots only at the highest concentration of $\mathrm{Cu}$ (Fig. 9). In Period 2, trees grafted onto SW showed no variation in the activity of APX, while RL-trees had an increased APX activity in the leaves when grown in solution with the highest concentration of $\mathrm{Cu}$ and a higher activity in roots when grown in either 0.015 or 24.0 $\mu \mathrm{M} \mathrm{Cu}$ (Fig. 9).

\section{Discussion}

Excess $\mathrm{Cu}$ directly damages the integrity of cellular ultrastructure in citrus trees (Zambrosi et al. 2013), and responses of antioxidant enzyme activities in plant leaves is dependent on the rootstock genotypes used (Hippler et al. 2016). In this study, we determined the effect of rootstocks with different horticultural characteristics and nutritional demand (Zambrosi et al. 2013, Mattos Jr et al. 2010) on responses of the photosynthetic rate, antioxidant activity and redistribution of metals within the vegetative parts of citrus trees exposed to $\mathrm{Cu}$ concentrations in two growth periods (Fig. 10). In Period 1, trees were grown in low, medium or high concentrations of $\mathrm{Cu}$ in the nutrient solution (Period 1), and the main effects of excess $\mathrm{Cu}$ were characterized. In the second period, when the same trees were grown without $\mathrm{Cu}$ addition in the nutrient solution (Period 2), metal redistribution to new plant parts was assessed, and the effects of $\mathrm{Cu}$ deficiency were most pronounced due to the extended period with limited nutrient availability (Fig. 10).

\section{Plant growth, $\mathrm{Cu}$ uptake, distribution and redistribution}

Plants grown on the lowest and highest concentrations of $\mathrm{Cu}$ decreased in plant biomass (Fig. 1) because of direct damage caused to photosynthesis (Fig. 5). Although trees grafted onto SW exhibited lower variation in biomass production compared to those grafted onto RL in Period 1 (Fig. 1), trees 
grafted onto RL grown in $24.0 \mu \mathrm{M}$ Cu exhibited higher recovery of growth of new vegetative flushes in Period 2, when plants were grown without the $\mathrm{Cu}$ supply in the nutrient solution (Fig. 1). On the other hand, trees grown in $0.015 \mu \mathrm{M} \mathrm{Cu}$ exhibited lower biomass production of new vegetative flushes and lower leaf area at the end of Period 2, compared to those grown in medium and high $\mathrm{Cu}$ concentrations (Fig. 1), which was probably due to the lower nutrient reserve in these trees that reduced $\mathrm{P}_{\mathrm{N}}$ (Fig. 5).

The accumulation of $\mathrm{Cu}$ occurred mainly in the roots, even after a period without the nutrient supply (Period 2); this ranged from $40 \%$ to $60 \%$ of total nutrient in the plants grown in $0.015 \mu \mathrm{M} \mathrm{Cu}$ and $24.0 \mu \mathrm{M} \mathrm{Cu}$ respectively (Fig. 3). Up to $80 \%$ of $\mathrm{Cu}$ in plants is likely partitioned to the roots when $\mathrm{Cu}$ supply is not suspended, as reported previously (Hippler et al. 2016, 2018a). The rootstocks accumulated different levels of $\mathrm{Cu}$ between coarse and fibrous roots, with a main accumulation in the coarse roots for trees grafted onto $\mathrm{SW}$, while $\mathrm{Cu}$ accumulation was evenly distributed within each root class for trees grafted onto RL (Fig. 3). Apple trees exposed to a high $\mathrm{Cu}$ level showed that $\mathrm{Cu}$ mobility to the canopy was most limited by accumulation of $\mathrm{Cu}$ in fibrous roots (Wang et al. 2016). In our study, trees grafted onto RL produced more fibrous roots than those grafted onto SW (Fig. 1) and, the former consequently accumulated more $\mathrm{Cu}$ (Fig. 3), which could be related with superior capacity of these plants to recover plant growth after an initial condition of excess $\mathrm{Cu}$ (Fig. 1).

Even though roots limited $\mathrm{Cu}$ transport to the canopy (Fig. 2), as a tolerance mechanism (Hippler et al. 2016, 2018b), the root system also represented the main endogenous pool of this nutrient for the new vegetative flush growth (Fig. 3). Copper redistributed to the new vegetative parts represented 10$15 \%$ of the basal $\mathrm{Cu}$ within the plant (Fig. 3). Copper redistribution from the old organs to the new vegetative organs is most likely to occur in citrus trees when they are well supplied with the nutrient at the root level. Therefore, considering the low mobility of metal micronutrients in the phloem of woody plants (Hippler et al. 2018b), our work emphasizes the importance of an adequate soil management plan to produce well-nourished plants by supplying nutrients not only to the canopy but also to the roots.

\section{Gas exchange measurements and photochemistry activity}

In this work, ETR was more affected in Period 1 compared to Period 2 (Fig. 5). Under $\mathrm{Cu}$ deficiency or toxicity conditions, the electron transport between the photosystems is most affected (Tanyolaç et al. 2007, Hippler et al. 2018a). Metal toxicity causes the photo-oxidation and dissipation of electrons, resulting in excessive formation of ROS (Gururani et al. 2015). We monitored high levels 
of ROS in PSII, after impairment of the electron transport from photosystem (PS)II to PSI, which would further affect the integrity of chlorophyll and photosynthetic activity of plants (Gururani et al. 2015).

In Period 1 , the reduction of $\mathrm{g}_{\mathrm{S}}$ was followed by a decrease in $\mathrm{P}_{\mathrm{N}}$, both caused by the $\mathrm{Cu}$-induced stress (Fig. 5). However, in Period 2, the reduction of $\mathrm{P}_{\mathrm{N}}$ was possibly not caused by the control of stomatal opening, since no change in $\mathrm{g}_{\mathrm{S}}$ and $\mathrm{C}_{\mathrm{i}}$ were verified for different $\mathrm{Cu}$ levels (Fig. 5). Damage to the antenna complex in PSII, which is responsible for receiving photons and converting it into energy for photosynthetic machinery (Baker et al. 2007), likely occurred, as suggested by the reduction of $\mathrm{P}_{\mathrm{N}} / \mathrm{C}_{\mathrm{i}}$ and the lower integrity of chlorophyll a (Fig. 6).

At the end of Period 2, trees grafted onto SW exhibited greater sensitivity of photosynthesis to $\mathrm{Cu}$ deficiency, as indicated with lower values of $\mathrm{P}_{\mathrm{N}}$ and $\mathrm{P}_{\mathrm{N}} / \mathrm{C}_{\mathrm{i}}$ in 0.015 and $0.60 \mu \mathrm{M} \mathrm{Cu}$, compared to those grafted onto RL (Fig. 5). Moreover, the reduction of $\mathrm{P}_{\mathrm{N}}$ and the constant values of ETR indicated that the number of electrons $\left(\mathrm{e}^{-}\right)$per $\mathrm{CO}_{2}$ molecule assimilated was higher in $\mathrm{SW}$ grown in low $\mathrm{Cu}$ levels (ETR/P $\mathrm{P}_{\mathrm{N}}$, Fig. 5). In this case, the $\mathrm{e}^{-}$excess causes the increase of ROS formation and consequently reduces the integrity of the photosynthetic apparatus. The highest values of AEF found in trees grafted onto $\mathrm{SW}$ grown in $0.015 \mu \mathrm{M}$ in both periods and those grafted onto RL grown in 0.015 $\mu \mathrm{M} \mathrm{Cu}$ in Period 1 and $24.0 \mu \mathrm{M} \mathrm{Cu}$ in Period 2 (Fig. 6) suggest that a greater proportion of electrons was directed to other sinks, such as photorespiration, Mehler's reaction or nitrogen metabolism, instead of the photosynthetic process per se (Miyake 2010). To reduce photo-oxidative damage and to dissipate excess energy (e) into heat, plants have a non-photochemical quenching system (qNP), which reduces the concentration of the excited state of chlorophyll (Yruela et al. 2013, Gururani et al. 2015). Variations of $\mathrm{qP}$ and $\mathrm{qNP}$ were observed in Period 2 in trees grown in $0.015 \mu \mathrm{M} \mathrm{Cu}$, suggesting that the photo-protective system effectively reduced the damage to PSII only under the lowest level of $\mathrm{Cu}$. However, the increase in $\mathrm{qP}$ observed only in trees grafted onto SW grown in $0.015 \mu \mathrm{M} \mathrm{Cu}$ (Fig. 6) indicated a less efficient absorption of photons during photosynthesis (Yruela et al. 2013), since more fluorescence was quenched by the photochemical process. This decreased the production of photo-assimilates necessary to achieve highest yield capacity (Syvertsen and GarciaSanchez 2014).

\section{ROS and antioxidant enzyme system}

The nutritional disorders caused either by deficiency or excess of $\mathrm{Cu}$ in plants promoted ROS accumulation, as indicated by the $\mathrm{H}_{2} \mathrm{O}_{2}$ and MDA levels observed in leaves and roots (Fig. 7). 
Accumulation of ROS, such as $\mathrm{OH}^{-}$and $\mathrm{H}_{2} \mathrm{O}_{2}$, in plant tissues increases lipid peroxidation (MDA content), and consequently the degradation of membranes and biomolecules (Piotto et al. 2014, Choudhury et al. 2016). Accumulation of $\mathrm{H}_{2} \mathrm{O}_{2}$ and MDA was higher in trees exposed to the highest concentration of $\mathrm{Cu}$ in Period 1 (Fig. 7). However, in Period 2 the trees grafted onto SW exhibited higher $\mathrm{H}_{2} \mathrm{O}_{2}$ concentrations in roots when grown on low metal concentration. This demonstrated greater sensitivity of this rootstock for the Cu-limited condition (Fig. 7). On the other hand, trees grafted onto RL exhibited a greater detoxification ability of ROS in the second period (Fig. 7), which was demonstrated by the increased activities of CAT and APX in both leaves and roots (Fig. 9). This greater efficiency in the elimination of ROS may also be related to the increased production of fibrous roots by RL (Fig. 1). These roots are more active when compared to the coarse roots due to the higher absorption and assimilation of nutrients or other organic compounds, and enzymatic activity (Wang et al. 2016).

In the case of ROS production, SOD activity was likely important in minimizing damage caused by either deficiency or excess of $\mathrm{Cu}$, especially since the activities in leaves and roots of the diverse isoforms were shown to be dependent on the citrus rootstock, with the main differences being observed in $\mathrm{Mn}$-SOD and $\mathrm{Cu} / \mathrm{Zn}$-SOD activities (Fig. 8). Although $\mathrm{Cu} / \mathrm{Zn}$-SOD activity has been considered dispensable for photosynthetic activity and the development of Arabidopsis thaliana after exposure to high concentrations of $\mathrm{Cu}$ and light intensity (Cohu et al. 2009), this isoform was shown to be important in the recovery of citrus plants to an excess condition of the metal, particularly for those grafted onto RL (Fig. 8). In leaves of citrus trees, the activity of $\mathrm{Cu} / \mathrm{Zn}$-SOD was more responsive to the different supply of Zn sources, while Mn-SOD and Fe-SOD slightly varied with different supplies of Mn (Hippler et al. 2015).

Under abiotic stress conditions, the balance of the activities of SOD, APX and CAT in plants is essential for determining the levels of $\mathrm{O}_{2} \cdot{ }^{-}$and $\mathrm{H}_{2} \mathrm{O}_{2}$ and other ROS, since a compensatory mechanism is needed if the balance of protective enzymes is modified (Azevedo et al. 1998, Choudhury et al. 2016). In this context, $\mathrm{H}_{2} \mathrm{O}_{2}$ scavenging was carried out by the activity of both CAT and APX in Period 1 (Fig. 9). Catalase activity, was then regulated by the citrus rootstock: the activity increased in leaves of trees grafted onto RL and roots of SW (Fig. 9). In this case, the CAT activity in leaves of RL at higher $\mathrm{Cu}$ concentration appeared to be more effective to maintain the photosynthetic activity, as indicated by the largest values of $\mathrm{P}_{\mathrm{N}}, \mathrm{g}_{\mathrm{S}}$ and $\mathrm{C}_{\mathrm{i}}$ (Fig. 5).

In Period 2, trees grafted onto RL exhibited an increase in the activities of CAT of roots and APX of leaves and roots when grown in $24.0 \mu \mathrm{M} \mathrm{Cu}$ allowing greater plant re-growth than those grafted 
onto SW (Figs. 1 and 10). Similar to citrus trees, increased activities of SOD followed by APX in sugarcane were important to prevent damages to the photosynthetic machinery of plants under drought stress (Sales et al. 2013). This emphasizes the importance of understanding the balance between activities of APX and CAT enzymes, and possibly other peroxidases which were not analysed in this study, which generally have a different role in the elimination of $\mathrm{H}_{2} \mathrm{O}_{2}$ (Gratão et al. 2015, Anjum et al. 2016, Hippler et al. 2018a).

\section{Copper and iron interactions in citrus trees}

Although three Fe-SOD isoforms were identified in roots, no activity was observed in trees grown in $24.0 \mu \mathrm{M} \mathrm{Cu}$ in Period 1 (Fig. 8). Plants exposed to high levels of metals such as $\mathrm{Cu}$ (Lequeux et al. 2010, Mattos Jr et al. 2010), Zn (Kendziorek et al. 2014), nickel (Ni) (Kuhmar et al. 2015) or cadmium (Cd) (Gratão et al. 2015) have shown decreases in Fe levels of shoots/leaves and increase in roots. In this case, $\mathrm{Fe}$ is likely to become unavailable to plant growth, as confirmed by the reduction in the Fe-SOD activity of both rootstocks, even given the greater accumulation of nutrients in roots when plants were grown in the highest concentration of $\mathrm{Cu}$ (Fig. 8).

At the end of Period 2, the redistribution of Fe from roots to canopy in trees that were grown in $24.0 \mu \mathrm{M} \mathrm{Cu}$ was greater in plants grafted onto RL than SW (Fig. 4). Plants have mechanisms that may limit the distribution of heavy metals in vegetative parts (Hall 2002), with histidine and nicotianamine identified to be important Cu-chelators in Brassica carinata (Irtelli et al. 2009) and with phytochelatins for $\mathrm{Cd}$ in citrus seedlings (López-Climent et al. 2014). On the other hand, tomato plants overexpressing AtHMA4, a $\mathrm{Zn}$ export protein involved in the control of the root to shoot metal translocation, showed limited Fe translocation from roots (Kenziorek et al. 2014). Therefore, chelating or transport limiting mechanisms would likely reduce Fe activity in the cells more significantly in trees grafted onto SW. The chelation probably mainly occurs in citrus roots, where it primarily accumulates (Figs. 2 and 3).

In conclusion, our data indicate that rootstocks regulate root-to-shoot communication under and after stress caused by $\mathrm{Cu}$ nutritional disorders. Regardless of the rootstock, citrus trees are sensitive to $\mathrm{Cu}$ excess. However, the trees grafted onto RL exhibited higher antioxidant enzymes activities in both roots and leaves upon $\mathrm{Cu}$ toxicity, which resulted in a greater integrity of the photosystem, a better assimilation of $\mathrm{CO}_{2}$ and a better plant growth. Even though trees grafted onto $\mathrm{SW}$ exhibited lower efficiency of the antioxidant enzymatic system, this rootstock likely limited the transport and redistribution of $\mathrm{Cu}$ from the roots more than $\mathrm{RL}$, which also limited Fe transport to the plant canopy. 
Since both rootstock genotypes of citrus used in this study accumulate more $\mathrm{Cu}$ in roots to maintain $\mathrm{Cu}$ homeostasis, redistribution of this metal from roots to new vegetative flushes is critical for plant growth under low availability of $\mathrm{Cu}$. This emphasizes the importance of an enhanced nutritional management with adequate $\mathrm{Cu}$ supply to roots to support plant nutrient demand in new growth parts.

\section{Author contributions}

F.W.R.H., D.M.J., J.A.Q. and R.M.B. designed the study. F.W.R.H. performed the experiment and laboratorial analysis. F.W.R.H. and V.L.D. performed photosynthetic evaluations. F.W.R.H. analyzed the data and F.W.R.H. and D.M.J. wrote the manuscript. R.M.B., R.A.A., V.L.D. and L.E.W. revised the manuscript. All authors have read and approved the final version of the manuscript.

Acknowledgements - The authors thank São Paulo Research Foundation (FAPESP, grant \#2015/13572-8 and \#2012/13917-7). We also thank the Conselho Nacional de Desenvolvimento Científico e Tecnológico (CNPq), which granted RMB, RAA and DMJ fellowships.

\section{References}

Alexieva V, Sergiev I, Mapelli E, Karanov E (2001) The effect of drought and ultraviolet radiation on growth and trees markers in pea and wheat. Plant Cell Environ 24: 1337-1344

Anjum NA, Sharma P, Gill SS, Hasanuzzaman M, Khan EA, Kachhap K, Mohamed AA, Thangavel P, Devi GD, Vasudhevan P, Sofo A, Khan NA, Misra AN, Lukatkin AS, Singh HP, Pereira E, Tuteja $\mathrm{N}$ (2016) Catalase and ascorbate peroxidase - representative $\mathrm{H}_{2} \mathrm{O}_{2}$-detoxifying heme enzymes in plants. Environ Sci Pollut Res 23: 19002-19029

Azevedo RA, Alas RM, Smith RJ, Lea PJ (1998) Response of antioxidant enzymes to transfer from elevated carbon dioxide to air ozone fumigation, in leaves and roots of wild-type and catalasedeficient mutant of barley. Physiol Plant 104: 280-292

Baker NR, Harbinson J, Kramer DM (2007) Determining the limitations and regulation of photosynthetic energy transduction in leaves. Plant Cell Environ 30: 1107-1125

Bataglia OC, Furlani AMC, Teixeira JPF, Furlani PR, Gallo JR (1983) Método de análise química de plantas. Instituto Agronomico, Campinas

Beauchamp CH, Fridovich I (1971) Superoxide dismutase: improved assays and an assay applicable to acrylamide gels. Anal Biochem 44: 276-287 
Behlau F, Fonseca AE, Belasque Jr J (2016) A comprehensive analysis of the Asiatic 
Heath RL, Packer L (1968) Photoperoxidation in isolated chloroplasts. I. Kinetics and stoichiometry of fatty acid peroxidation. Arch Biochem Biophys 125: 189-198

Hippler FWR, Boaretto RM, Quaggio JA, Azevedo RA, Mattos-Jr D (2015) Towards soil management with $\mathrm{Zn}$ and Mn: estimates of fertilization efficacy of Citrus trees. Ann Appl Biol 166: 484-495

Hippler FWR, Boaretto RM, Dovis VL, Quaggio JA, Azevedo RA, Mattos-Jr D (2018a) Oxidative stress induced $\mathrm{Cu}$ nutritional disorders in Citrus depends on nitrogen and calcium availability. Sci Rep 8: 1641.

Hippler FWR, Cipriano DO, Boaretto RM, Quaggio JA, Gaziola SA, Azevedo RA, Mattos-Jr D (2016) Citrus rootstocks regulate the enzymatic and nutritional status and antioxidant system of trees under copper stress. Environ Exp Bot 130: 42-52

Hippler FWR, Petená G, Boaretto RM, Quaggio JA, Azevedo RA, Mattos-Jr D (2018b) Mechanisms of copper stress alleviation in Citrus trees after metal uptake by leaves or roots. Environ Sci Pollut Res doi.org/10.1007/s11356-018-1529-x

Irtelli B, Petrucci WA, Navari-Izzo F (2009) Nicotianamene and histidine/proline are, respectively, the most importeat copper chelators in xylem sap of Brassica carinata under conditions of copper deficiency and excess. J Exp Bot 60: 269-277

Juraniec M, Lequeux H, Hermans C, Willems G, Nordborg M, Schneeberger K, Salis P, Vromant M, Lutts S, Verbruggen N (2013) Towards the discovery of novel genetic component involved in stress resistence in Arabidopsis thaliana. New Phytol 201: 810-824

Kendziorek M, Barabasz A, Rudzka J, Tracz K, Mills RF, Williams LE, Antosiewicz DM (2014) Approach to engineer tomato by expression of AtHMA4 to enhance $\mathrm{Zn}$ in the aerial parts. J Plant Physiol 171: 1413-1422

Kraus TE, McKersie BD, Fletcher RA (1995) Paclobutrazol-induced tolerance of wheat leaves to paraquat may involve increased antioxidant enzyme activity. J Plant Physiol 145: 570-576

Komárek M, Van k A, Chrastny V, Szakova J, Kubova K, Drahota P, Balik J (2009) Retention of copper originating from different fungicides in contrasting soil types. J Hazard Mater 166: 13951402

Kuhmar P, Rouphael Y, Cardarelli M, Colla G (2015) Effect of nickel and grafting combination on yield, fruit quality, antioxidative enzyme activities, lipid peroxidation, and mineral composition of tomato. J Plant Nutr Soil Sci 178: 848-860 
Lequeux H, Hermans C, Lutts S, Verbruggen N (2010) Response to copper excess in Arabidopsis thaliana: Impact on the root system architecture, hormone distribution, lignin accumulation and mineral profile. Plant Physiol Biochem 48: 673-682

López-Climent MF, Arbona V, Pérez-Clemente RM, Zandalinas SI, Gómez-Cadenas A (2014) Effect of cadmium and calcium treatments on phytochelatin and glutathione levels in citrus plants. Plant Biol 16: 79-87

Macho-Rivero MA, Camacho-Cristóbal JJ, Herrera-Rodríguez MB, Müller M, Munné-Bosch S, González-Fontes A (2017) Abscisic acid and transpiration rate are involved in the response to boron toxicity in Arabidopsis plants. Physiol Plant 160: 21-32

Martínez-Ballesta MC, Alcaraz-López C, Muriez B, Mota-Cadenas C, Carvajal M (2010) Physiological aspects of rootstock-scion interactions. Sci Hort 127: 112-118

Mattos Jr D, Ramos UM, Quaggio JA, Furlani PR (2010) Nitrogênio e cobre na produção de mudas de citros em diferentes porta-enxertos. Bragantia 69: 135-147

Miyake C (2010) Alternative electron flows (water-water cycle and cyclic electron flow around PSI) in photosynthesis: molecular mechanisms and physiological functions. Plant Cell Physiol 51: 19511963

Nakano Y, Asada K (1981) Hydrogen peroxide is scavenged by ascorbate-specific peroxidase in spinach chloroplasts. Plant Cell Physiol 22: 867-880

Prasch CM, Sonnewald U (2015) Signaling events in plants: stress factors in combination change the picture. Environ Exp Bot 114: 4-14

Piotto FA, Tulmann-Neto A, Franco MG, Boaretto LF, Azevedo RA (2014) Rapid screening for selection of heavy metal-tolerant plants. Crop Breed Appl Biotechnol 14: 1-7

Sales CRG, Ribeiro RV, Silveira JAG, Machado EC, Martins MO, Lagôa AMMA (2013) Superoxide dismutase and ascorbate peroxidase improve the recovery of photosynthesis in sugarcane plants subjected to water deficit and low substrate temperature. Plant Physiol Biochem 73: 326-336

Schreiber U, Bilger W, Neubauer C (1994) Chlorophyll fluorescence as a nonintrusive indicator for rapid assessment of in vivo photosynthesis. In: Schulze ED, Caldwell MM Eds Ecophysiology of Photosynthesis. Springer, Berlin, pp 49-70

Syvertsen JP, Garcia-Sanchez F (2014) Multiple abiotic stresses occurring with salinity stress in citrus. Environ Exp Bot 103: 128-137

Tanyolaç D, Ekmekçi Y, Ünalan S (2007) Changes in photochemical and antioxidant enzyme activities in maize (Zea mays L.) leaves exposed to excess copper. Chemosphere 67: 89-98 
Yruela I (2013) Transition metals in plant photosynthesis. Metallomics 5: 1090-1109

Wang QY, Liu JS, Hu B (2016) Integration of copper subcellular distribution and chemical forms to understand copper toxicity in apple trees. Environ Exp Bot 123: 125-131

Zambrosi FCB, Mesquita GL, Tanaka FAO, Quaggio JA, Mattos Jr D (2013) Phosphorous availability and rootstock affect copper-induced damage to the root ultra-structure of Citrus. Environ Exp Bot 95: $25-33$

Zandalinas SI, Belfagón D, Arbona V, Gómez-Cadenas A (2017) Regulation of citrus responses to the combined action of drought and high temperatures depends on the severity of water deprivation. Physiol Plant 162: 427-438 
Fig. 1 Dry mass (DM) of young sweet oranges grafted onto Swingle citrumelo (SW) or Rangpur lime $(\mathrm{RL})$ after 110 days (Period 1) with different copper $(\mathrm{Cu})$ levels in the nutrient solution and after an additional 140 days (Period 2) without $\mathrm{Cu}$ supply. Legend: Coarse roots $>3 \mathrm{~mm} \emptyset$; Fibrous roots $\mathrm{d} 3$ $\mathrm{mm} \varnothing ; \mathrm{Cu}$ rates and rootstocks means followed by different lowercase or uppercase letters, respectively, are significantly different by the Tukey test $(P<0.05)$.

Fig. 2 Copper $(\mathrm{Cu})$ concentrations in young sweet oranges grafted onto Swingle citrumelo (SW) or Rangpur lime (RL) after 110 days (Period 1) with different copper $(\mathrm{Cu})$ levels in the nutrient solution and after an additional 140 days (Period 2) without $\mathrm{Cu}$ supply. Legend: Coarse roots $>3 \mathrm{~mm} \varnothing$; Fibrous roots $\mathrm{d} 3 \mathrm{~mm} \varnothing$; $\mathrm{Cu}$ rates and rootstocks means followed by different lowercase or uppercase letters, respectively, are significantly different by the Tukey test $(P<0.05)$.

Fig. 3 Accumulation and partitioning of copper $(\mathrm{Cu})$ in sweet oranges trees grafted onto Swingle citrumelo (SW) or Rangpur lime (RL) at the end of Period 2 (after 140 days without $\mathrm{Cu}$ supply). Legend: Coarse roots $>3 \mathrm{~mm} \varnothing$; Fibrous roots $\mathrm{d} 3 \mathrm{~mm} \varnothing$; $\mathrm{Cu}$ rates and rootstocks means followed by different lowercase or uppercase letters, respectively, are significantly different by the Tukey test $(P<0.05)$.

Fig. 4 Accumulation of iron $(\mathrm{Fe})$ in new leaves, course roots and fibrous roots of sweet oranges trees grafted onto Swingle citrumelo (SW) or Rangpur lime (RL) at the end of Period 2 (after 140 days without $\mathrm{Cu}$ supply). Legend: Coarse roots $>3 \mathrm{~mm} \emptyset$; Fibrous roots $\mathrm{d} 3 \mathrm{~mm} \emptyset$; $\mathrm{Cu}$ rates and rootstocks means followed by different lowercase or uppercase letters, respectively, are significantly different by the Tukey test $(P<0.05)$.

Fig. 5. Photosynthetic rate $\left(P_{N}\right)$, stomatal conductance $\left(g_{S}\right)$, internal $\mathrm{CO}_{2}$ concentration $\left(C_{i}\right)$, apparent electron transport rate (ETR), instantaneous carboxylation efficiency $\left(P_{N} / C_{i}\right)$ and ratio between ETR and $P_{N}\left(\mathrm{ETR} / P_{N}\right)$ in leaves of young sweet oranges grafted onto Swingle citrumelo (SW) or Rangpur lime (RL) after 110 days (Period 1) with different copper $(\mathrm{Cu})$ levels in the nutrient solution and after an additional 140 days (Period 2) without $\mathrm{Cu}$ supply. Legend: $\mathrm{Cu}$ rates and rootstocks means followed by different lowercase or uppercase letters, respectively, are significantly different by the Tukey test $(P<0.05)$. 
Fig. 6 The potential $\left(\mathrm{F}_{\mathrm{V}} / \mathrm{F}_{\mathrm{M}}\right)$ and effective $\left(\mathrm{F} / \mathrm{F}_{\mathrm{M}}\right.$ ') quantum yield of photosystem II (PSII); the alternative electron flows (AEF); and the photochemical $(q P)$ and non-photochemical quenching $(q N P)$ in leaves of young sweet oranges grafted onto Swingle citrumelo (SW) or Rangpur lime (RL) after 110 days (Period 1) with different copper $(\mathrm{Cu})$ levels in the nutrient solution or after an additional 140 days (Period 2) without $\mathrm{Cu}$ supply. Legend: $\mathrm{Cu}$ rates and rootstocks means followed by different lowercase or uppercase letters, respectively, are significantly different by the Tukey test $(P<0.05)$.

Fig. 7 Hydrogen peroxide $\left(\mathrm{H}_{2} \mathrm{O}_{2}\right)$ and lipid peroxidation (MDA) in leaves and roots of young sweet oranges grafted onto Swingle citrumelo (SW) or Rangpur lime (RL) after 110 days (Period 1) with different copper $(\mathrm{Cu})$ levels in the nutrient solution and after an additional 140 days (Period 2) without $\mathrm{Cu}$ supply. Legend: $\mathrm{Cu}$ rates and rootstocks means followed by different lowercase or uppercase letters, respectively, are significantly different by the Tukey test $(P<0.05)$.

Fig. 8 Superoxide dismutase (SOD) activity in polyacrylamide gel electrophoresis (PAGE 12\%) in leaves and roots of young sweet oranges grafted onto Swingle citrumelo (SW) or Rangpur lime (RL) after 110 days (Period 1) with different copper $(\mathrm{Cu})$ levels in the nutrient solution and after an additional 140 days (Period 2) without Cu supply. Legend: Std - bovine SOD standard.

Fig. 9 Catalase (CAT) and ascorbate peroxidase (APX) activities in leaves and roots of young sweet oranges grafted onto Swingle citrumelo (SW) or Rangpur lime (RL) after 110 days (Period 1) with different copper $(\mathrm{Cu})$ levels in the nutrient solution and after an additional 140 days (Period 2) without $\mathrm{Cu}$ supply. Legend: $\mathrm{Cu}$ rates and rootstocks means followed by different lowercase or uppercase letters, respectively, are significantly different by the Tukey test $(P<0.05)$.

Fig. 10 General view of the antioxidant enzymatic system in leaves and roots and the photosynthetic apparatus in leaves of young sweet orange plants, grafted onto two contrasting rootstocks [Swingle citrumelo (SW) or Rangpur lime (RL)] and grown in three different $\mathrm{Cu}$ concentrations (low - 0.015; medium - 0.60; and high $-24.0 \mu \mathrm{M} \mathrm{Cu}$ ) in Period 1 and without $\mathrm{Cu}$ supply in Period 2. Arrows represent up-regulated (up arrow), down-regulated (down arrow) or no alteration (horizontal bar) from the control plants $(0.60 \mu \mathrm{M} \mathrm{Cu})$. Legend: $\mathrm{H}_{2} \mathrm{O}_{2}$, hydrogen peroxide content; MDA, lipid peroxidation; $\mathrm{Cu} / \mathrm{Zn}-\mathrm{SOD}, \mathrm{Mn}-\mathrm{SOD}$ and $\mathrm{Fe}-\mathrm{SOD}$, isoforms of superoxide dismutase; CAT, catalase; 
APX, ascorbate peroxidase; $P_{N} / g_{S} / C_{i}$, leaf gas exchange measurements; Fluor $C h l a$, fluorescence of chlorophyll $a$ measurements; ETR, apparent electron transport rate. 
Coarse roots
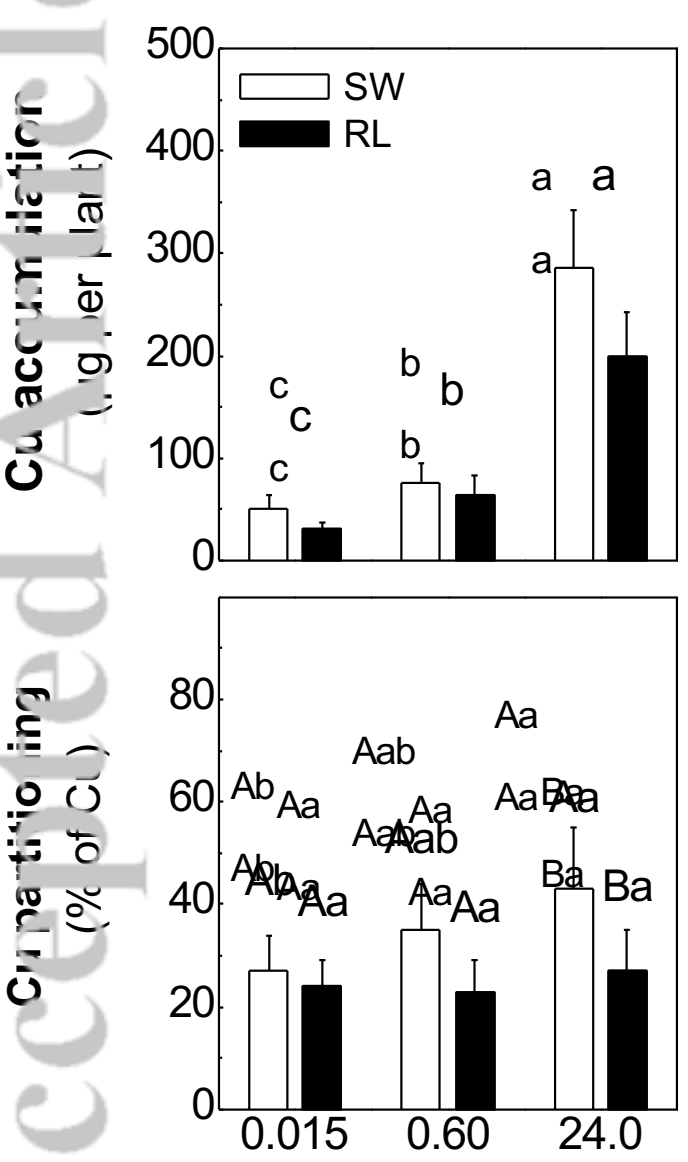

Fibrous roots
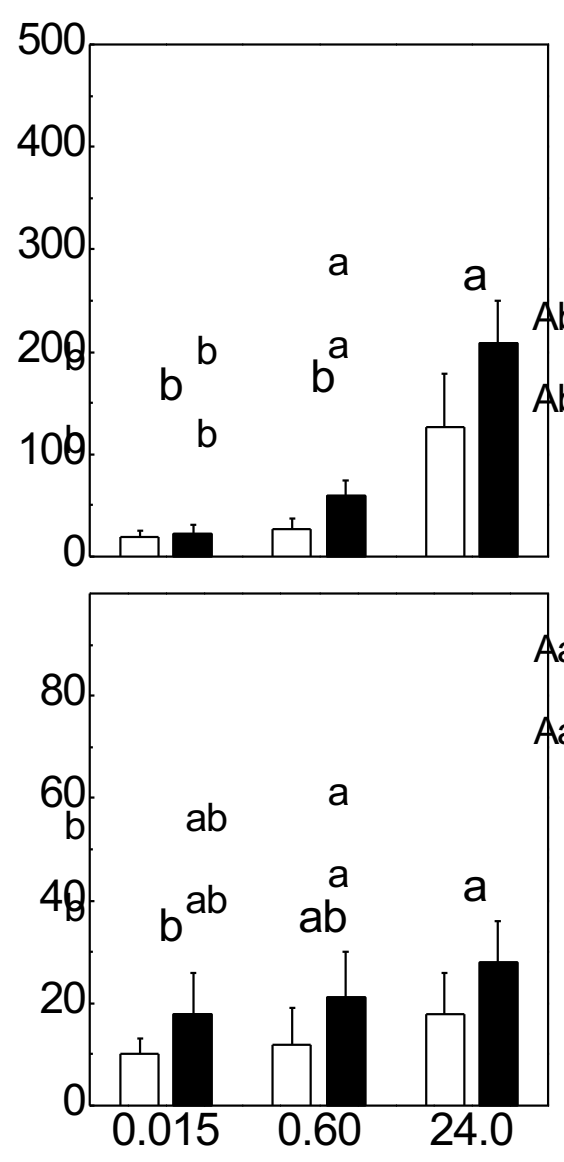

Old vegetative parts
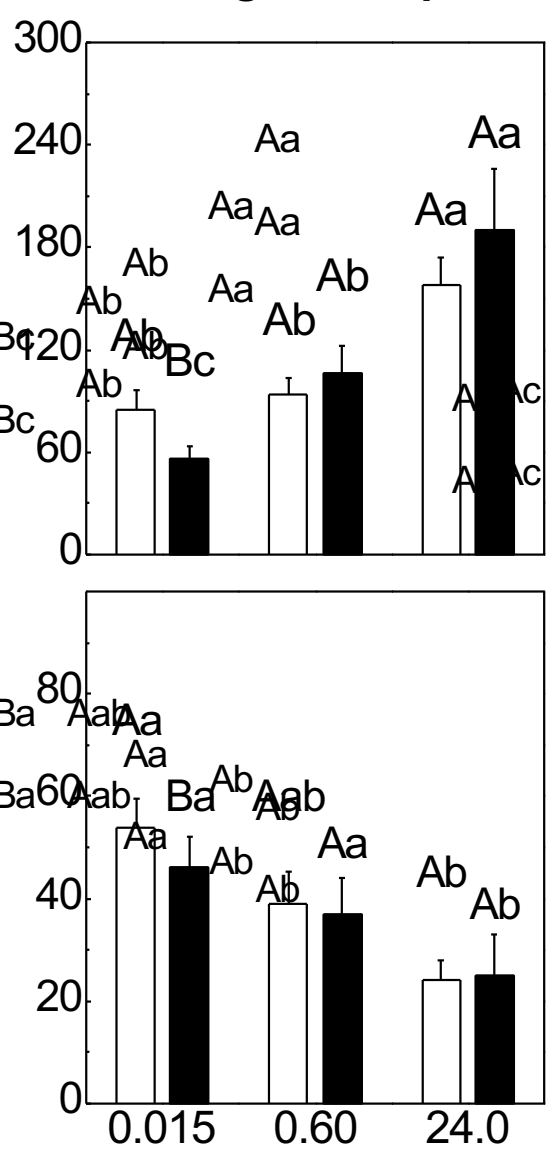

New vegetative parts
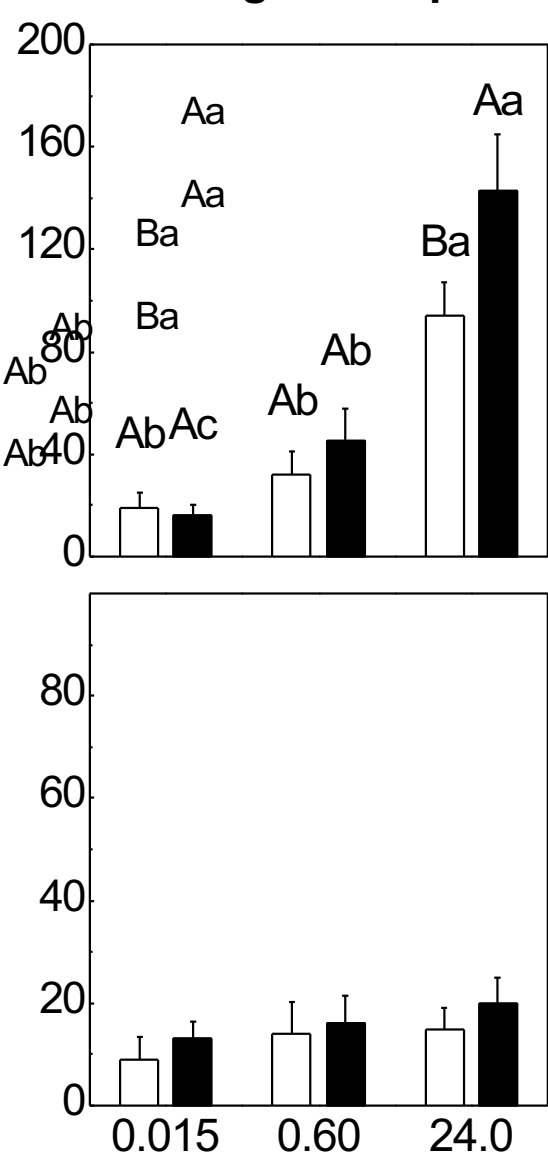

This article is protected by copuright All rights reserved. 
Period 1
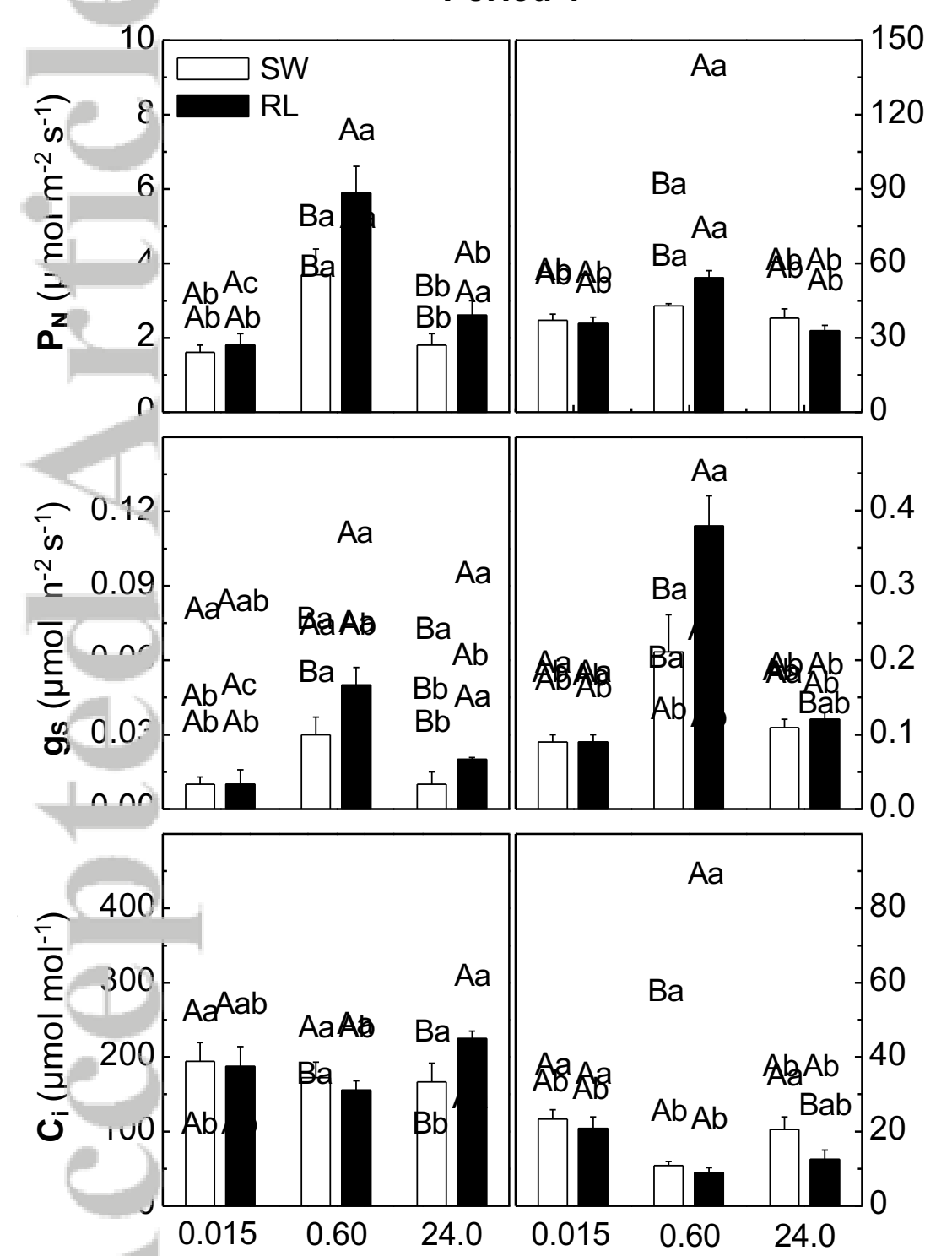

Period 2
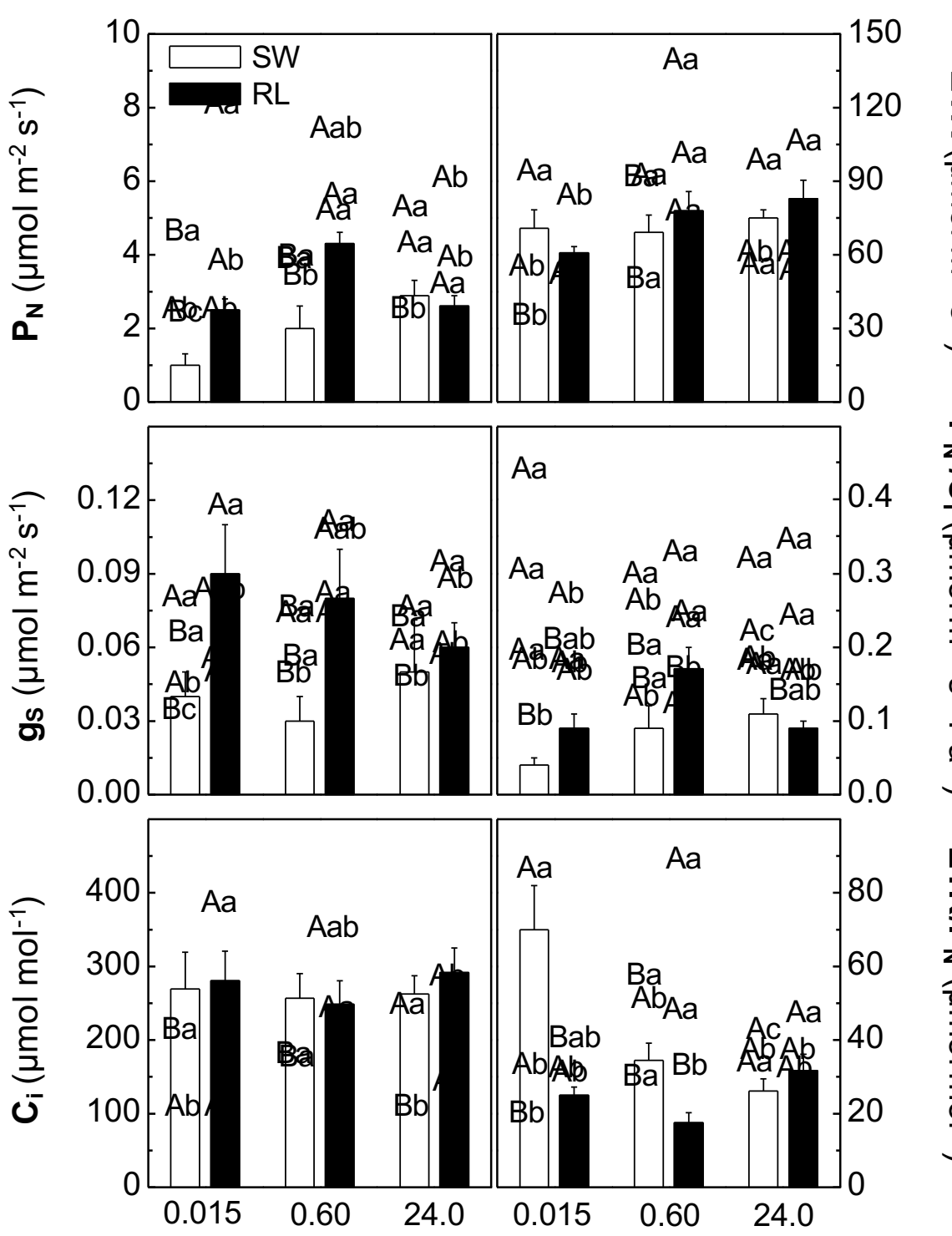

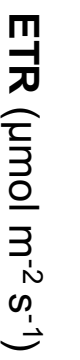

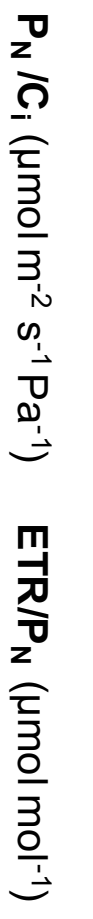

Cu concentration $(\mu \mathrm{M})$ This article is protected by copyright. All rights reserdegdentration $(\mu \mathrm{M})$ 


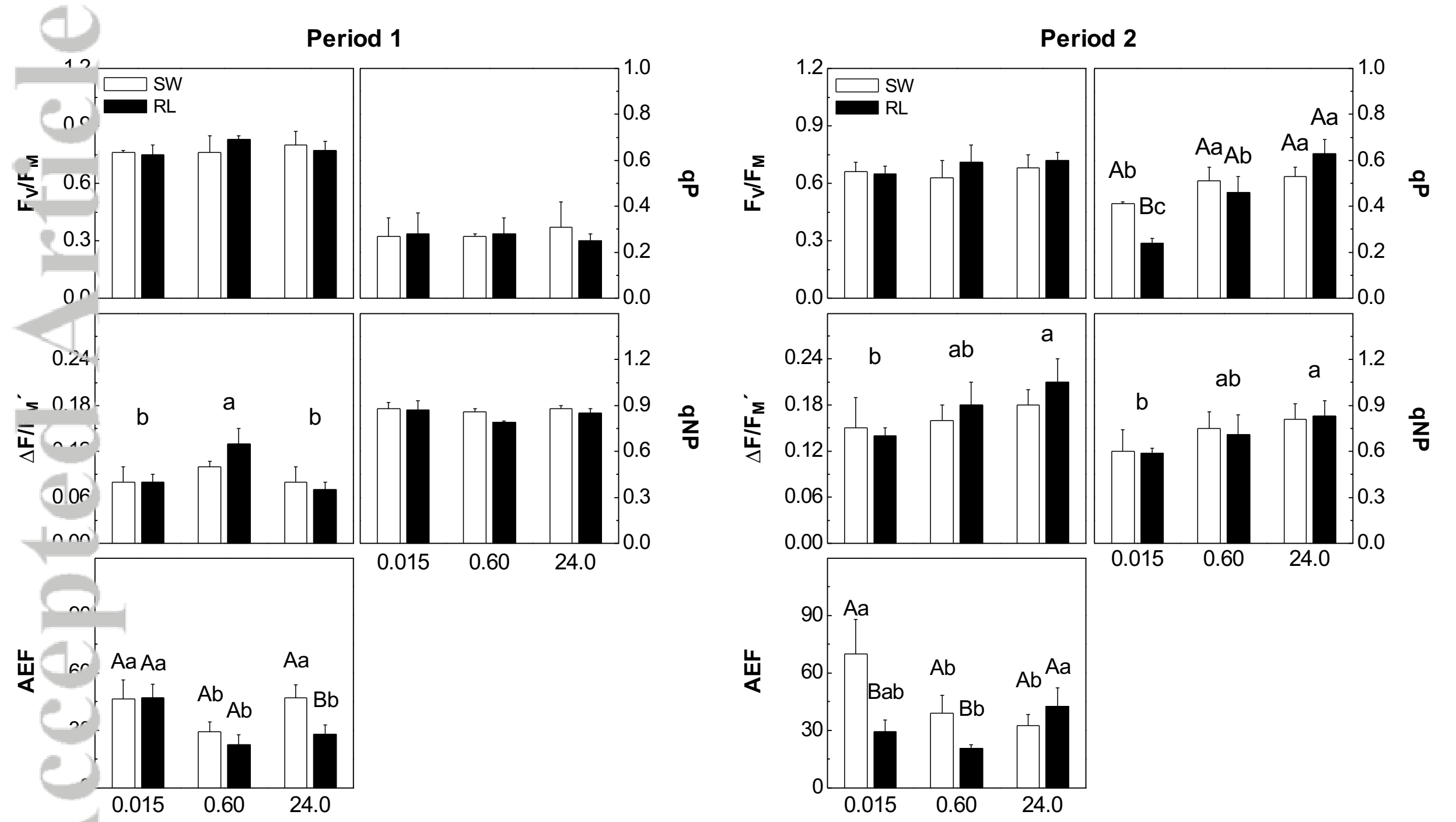

Cu concentration $(\mu \mathrm{M})$ This article is protected by copyright. All rightsceesebkedentration $(\mu \mathrm{M})$ 


\section{Period 1}

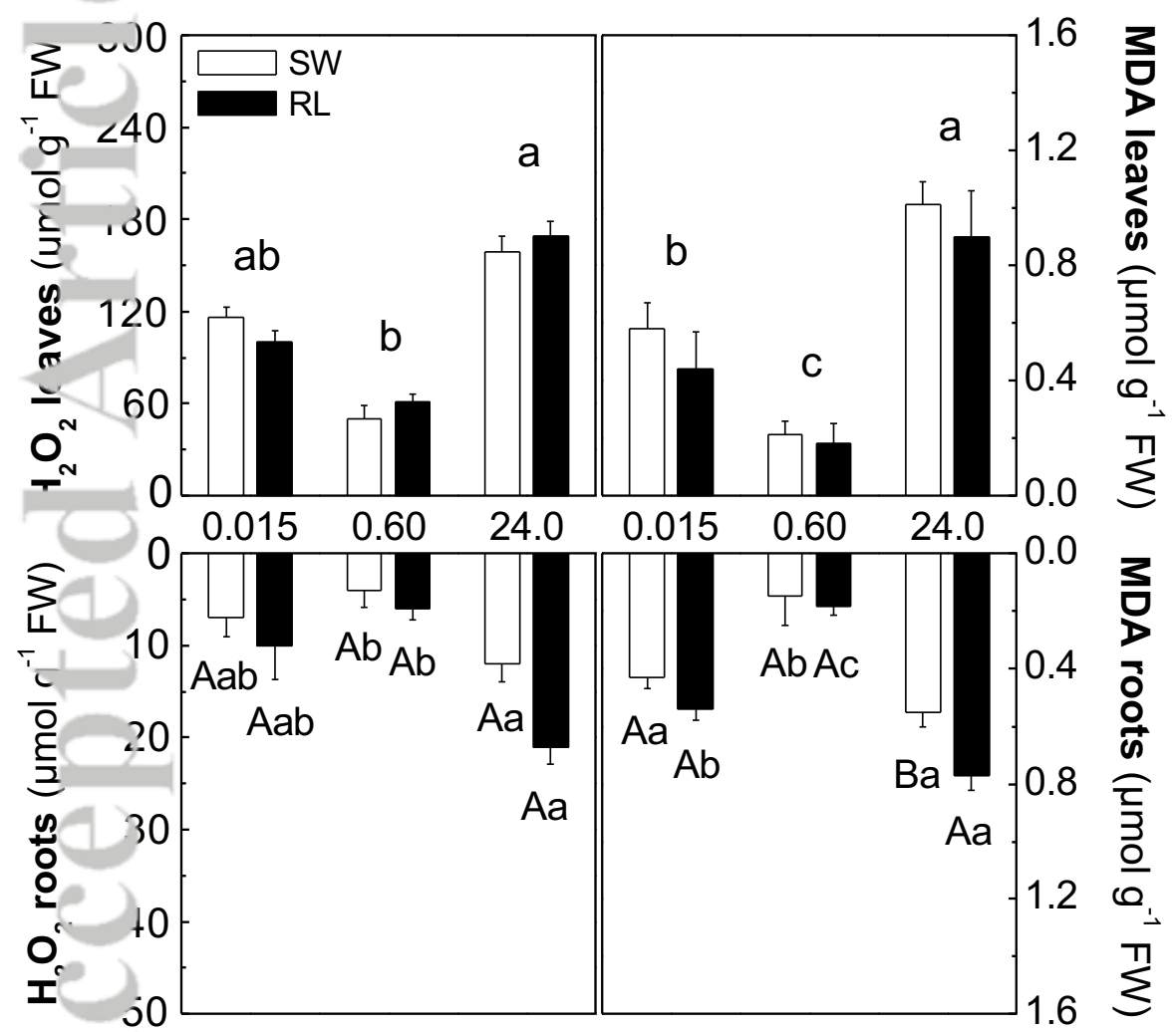

Period 2

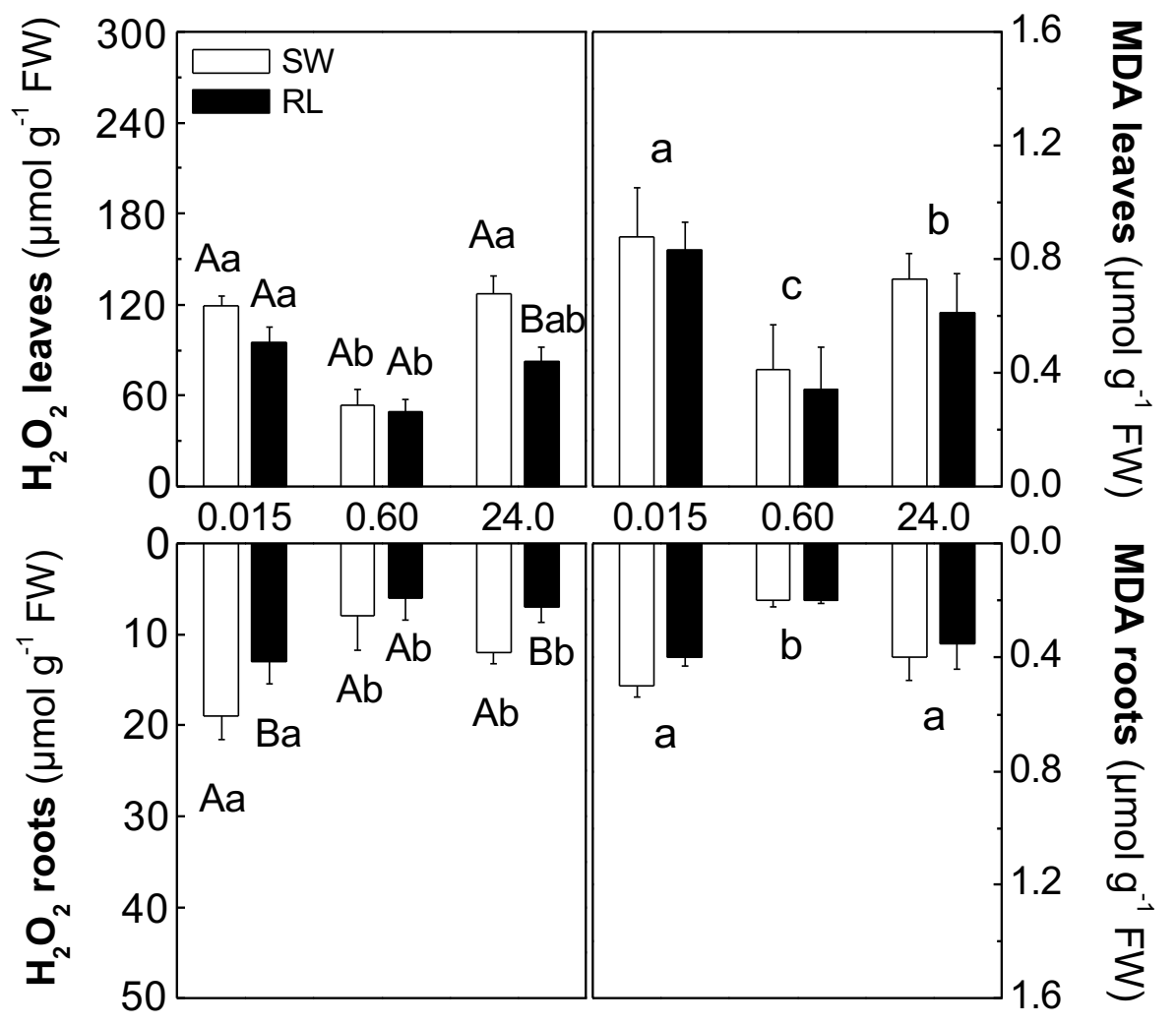

Cu concentration $(\mu \mathrm{M}){ }^{\text {This article is protected by copyright. All rights reserved. }}$ concentration $(\mu \mathrm{M})$ 


\section{Period 1}
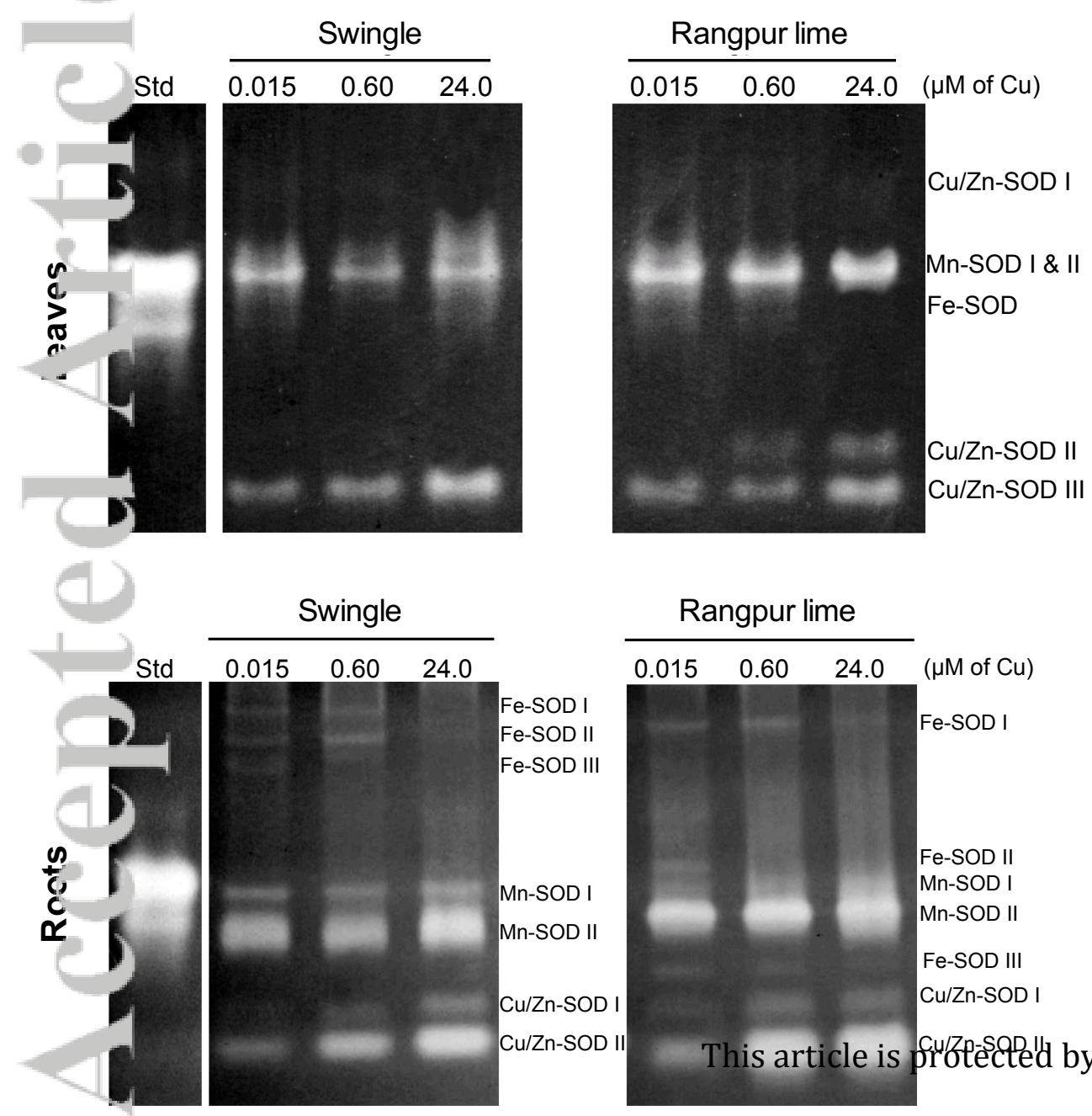

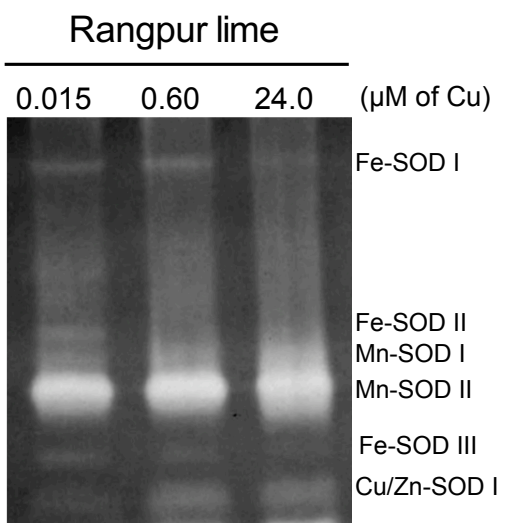

\section{Period 2}
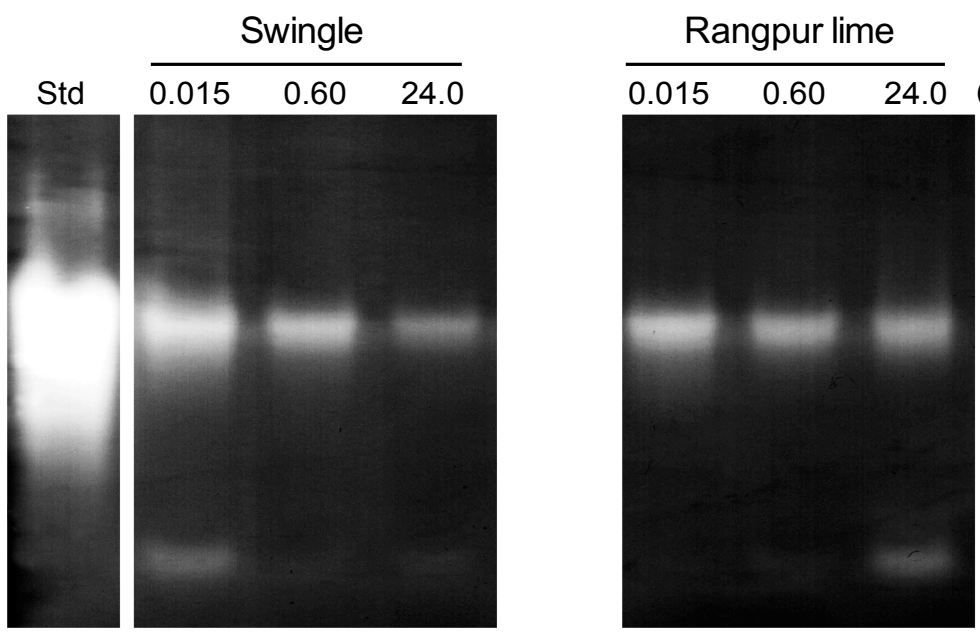

( $\mu \mathrm{M}$ of $\mathrm{Cu})$

Cu/Zn-SOD I

Mn-SOD I \& II

Fe-SOD

Cu/Zn-SOD II $\mathrm{Cu} / \mathrm{Zn}-\mathrm{SOD}$ III

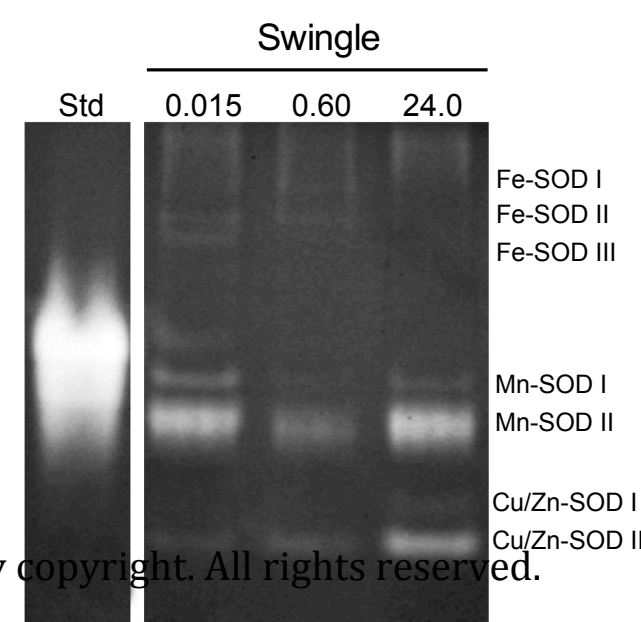

Rangpur lime

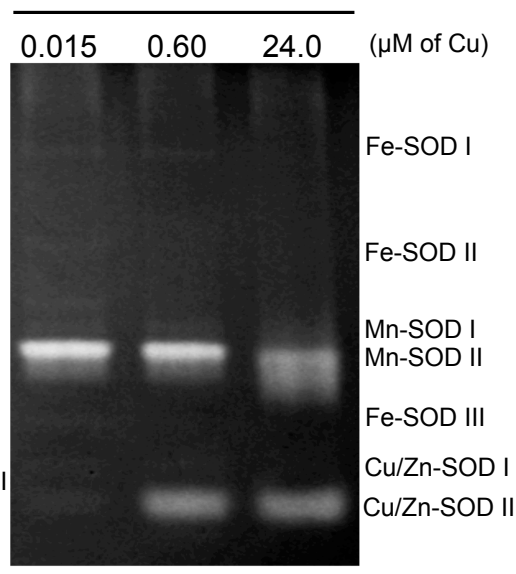




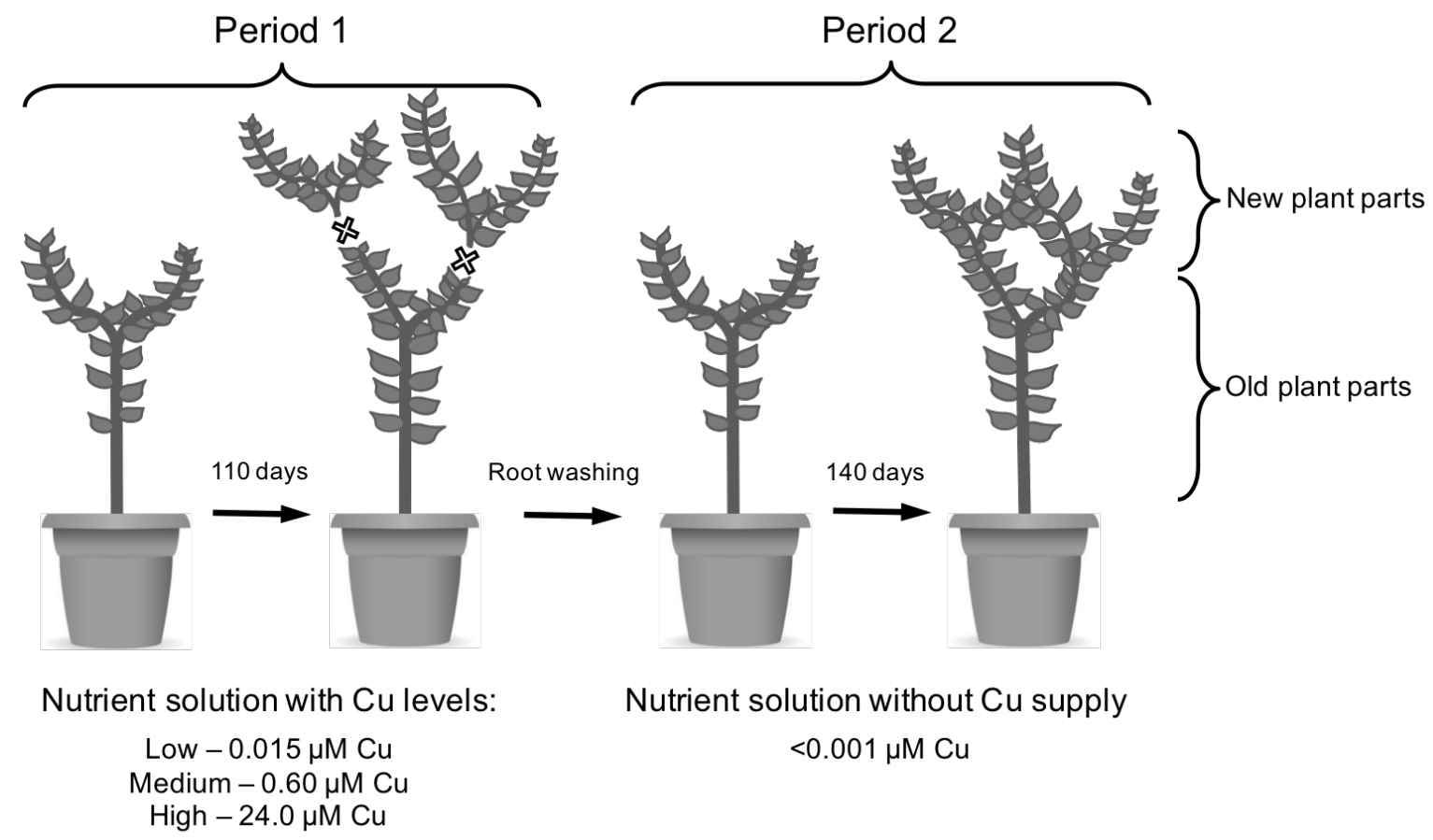

Appendix - Figure S1. Diagram of experimental treatments that consisted on two evaluation periods. Period 1: plants grown for 110 days in different $\mathrm{Cu}$ concentrations in the nutrient solution. When the 'New parts' were physiologically mature (leaves and twigs), the first set of analyses was performed, and new vegetative parts were removed. Period 2: plants grown for 14 days in the nutrient solution without $\mathrm{Cu}$ supply with the "New parts" mature, another set of analyses was performed, and plants were destructively harvested. 